\title{
Chemical variability of Al-Ti-Fe-Mg minerals in peraluminous granitoid rocks from Central Spain
}

\author{
CARLOS VILLASECA \& LUIS BARBERO ${ }^{1}$
}

\author{
Dpto. Petrología y Geoquímica, Fac. C. C. Geológicas, Universidad Complutense, \\ 28040 Madrid, Spain
}

\begin{abstract}
Two broad series of peraluminous granite types can be distinguished in the Central System of Spain. The first group consists of cordierite-bearing granites that are moderately peraluminous in composition (peraluminous S-type granites, PS). The second is composed of amphibole/allanite-bearing granites, weakly peraluminous in composition (peraluminous I-type, PI). These granite types evolved through complex igneous fractionation processes.

Both peraluminous granite types show differences in the chemical composition of biotite and cordierite; cordierite is common in PS granites but restricted to some highly fractionated PI granites. Garnet and ilmenite cannot be used as chemical criteria for distinguishing the two series.

The $\mathrm{Al}$ and $\mathrm{Na}$ content of biotite and cordierite correlate well with the granite type (PS and PI). The higher Na content in biotite (and cordierite) of PS granites is noteworthy. When plotted in a $\mathrm{Na} v s .{ }^{[\mathrm{VI}]} \mathrm{Al}$ diagram biotites are located in different fields according to the peraluminosity degree of the granite type. The estimated $\mathrm{Fe}^{3+} /\left(\mathrm{Fe}^{3+}+\mathrm{Fe}^{2+}\right)$ ratio of biotite is higher in PI than in PS granites, although this value is very pluton-dependent.

Several compositional variations of $\mathrm{Al}-\mathrm{Ti}-\mathrm{Fe}-\mathrm{Mg}$ (ATFM) minerals are functions of the degree of fractionation or evolution of the magma, irrespectively of its peraluminosity. Other chemical features of ATFM phases, such as $\mathrm{X}_{\mathrm{Fe}}$ or $\mathrm{X}_{\mathrm{Mn}}$, can be used as fractionation indices. Thus, the more acid the magma, the higher $\mathrm{X}_{\mathrm{Fe}}$ and $\mathrm{X}_{\mathrm{Mn}}$ in ATFM minerals. This correlation is not linear showing a rapid increase for silica values of $\mathrm{SiO}_{2} \geq 74 \%$. Usually, $\mathrm{X}_{\mathrm{Fe}}$ garnet $>\mathrm{X}_{\mathrm{Fe}}$ biotite $>\mathrm{X}_{\mathrm{Fe}}$ cordierite, and $\mathrm{X}_{\mathrm{Mn}}$ ilmenite $\cong \mathrm{X}_{\mathrm{Mn}}$ garnet $>\mathrm{X}_{\mathrm{Mn}}$ cordierite $>\mathrm{X}_{\mathrm{Mn}}$ biotite, while $\mathrm{X}_{\mathrm{Fe}}$ and $\mathrm{X}_{\mathrm{Mn}}$ of whole rock are very close to biotite values. The high increase in Mn content, more marked than in $\mathrm{Fe}$, in all AFM phases in the silica-rich granites $\left(\mathrm{SiO}_{2} \cong 74 \%\right)$, can be interpreted as a consequence of the incompatible behaviour of this element in highly evolved granites, that are sufficiently poor in $\mathrm{Ti}, \mathrm{Mg}$ and $\mathrm{Fe}$ to prevent or diminish crystallization of ore-minerals, such as ilmenite.
\end{abstract}

Key-words: Hercynian peraluminous granitoids, mineral-whole rock correlation, Al-Ti-Fe-Mg minerals (biotite, cordierite, garnet, ilmenite), Central Spain.

\section{1.- Introduction}

In recent years special attention has been payed to the significance and origin of aluminous minerals in granitoids characterised by varying degrees of peraluminosity. The discussion has been focused on the magmatic (restite/igneous fractionation) or xenolithic character of these minerals (Clarke, 1981; Chappell et al., 1987; Clemens \& Wall, 1988). There is an established framework describing the crystallization sequence of the AFM minerals along with mag- 


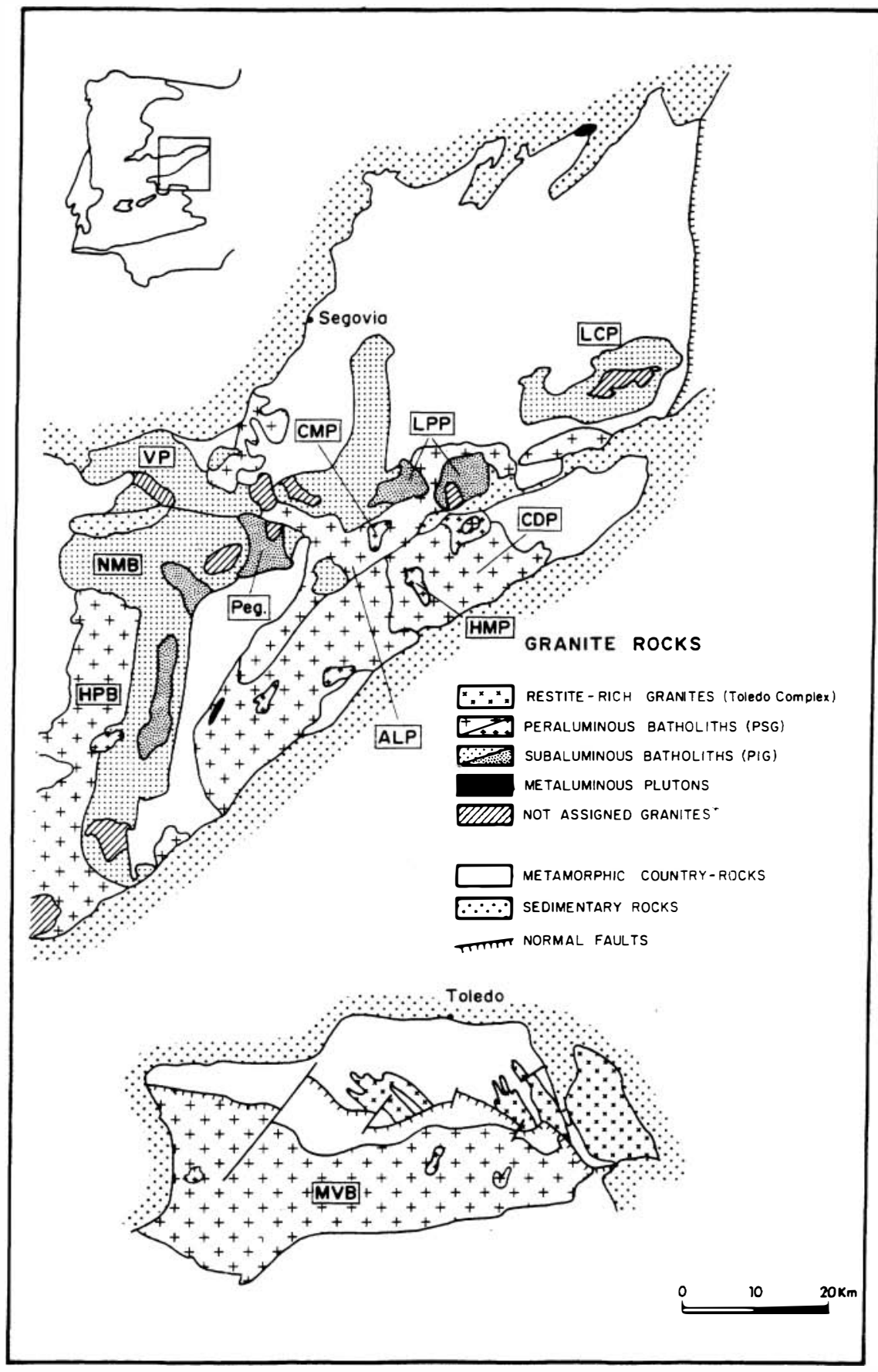

Fig. 1. Geological map of the Central Spain Region (Hercynian orogen). LCP $=$ La Cabrera pluton; LPP $=$ La Pedriza pluton; VP = Villacastín pluton; $\mathrm{NMB}=$ Las Navas del Marqués batholith; HPB = Hoyo de Pinares batholith; HMP = Hoyo de Manzanares pluton; $\mathrm{CMP}=$ Cabeza Mediana pluton; $\mathrm{Peg}=$ Peguerinos pluton; $\mathrm{ALP}=$ Alpedrete pluton; $\mathrm{CDP}=\mathrm{El}$ Cardín pluton; $\mathrm{MVB}=$ Mora-Las Ventas batholith. In peraluminous and subaluminous batholiths the smaller symbols indicate leucocratic varieties. 
matic evolution in peraluminous and subaluminous granitoids (Abbott \& Clarke, 1979; Abbott, 1981; Speer, 1981; Speer \& Becker, 1992). In these studies, the relatively late-magmatic character of some peraluminous phases (aluminum silicates, cordierites and Mn-garnets) is evidenced. This fact is also clear in the experimental works of Puziewicz \& Johannes (1988) and Shimura et al. (1992).

The late-Hercynian plutonism of the Spanish Central Region has been studied in detail during the last ten years (Brandebourger, 1984; Casillas, 1989; Andonaegui, 1990; Pérez-Soba, 1991; Villaseca et al., 1993), focussing attentión not only to petrography, geochemistry and geochronology, but also on mineral chemistry of the different granitic types. This work studies the chemical behaviour of the main Al-Ti-Fe-Mg (hereafter ATFM) minerals in these late-Hercynian granites (that is biotites, cordierites, garnets, ilmenites and aluminum silicates) with two main objectives: i) the characterization of the chemical composition of the ATFM phases between the two granitic groups of Central Spain stressing the potential of their use as chemical discriminators of peraluminous granitic series; ii) the chemical evolution of ATFM minerals with descending temperature.
As observed by Speer \& Becker (1992) investigating sequences of magmatic ATFM mineral crystallization reactions in granites is difficult because it is necessary to rely on observations from different samples or even different rock types of composite plutons. Following these authors we assume that the relationships among the samples or rock types represent parts of a continous liquid line of descent.

\section{2.- Granite types in the Spanish Central Region}

The Spanish Central Region comprises the eastern part of the Spanish Central System and the area south of Toledo (Fig. 1). This region is characterized by the great volume of epizonal granitoids emplaced into pre-Cambrian and Palaeozoic metamorphic rocks. The magmatic episode is essentially late with respect to the main Hercynian tectono-metamorphic events of the area. $\mathrm{Rb}-\mathrm{Sr}$ ages of these granites range from $345 \mathrm{Ma}$ to $275 \mathrm{Ma}$ (Vialette et al., 1981; Ibarrola et al., 1987), although there seems to be an intrusive climax between $325 \mathrm{Ma}$ and $288 \mathrm{Ma}$ (Andonaegui, 1990; Pérez-Soba, 1991).

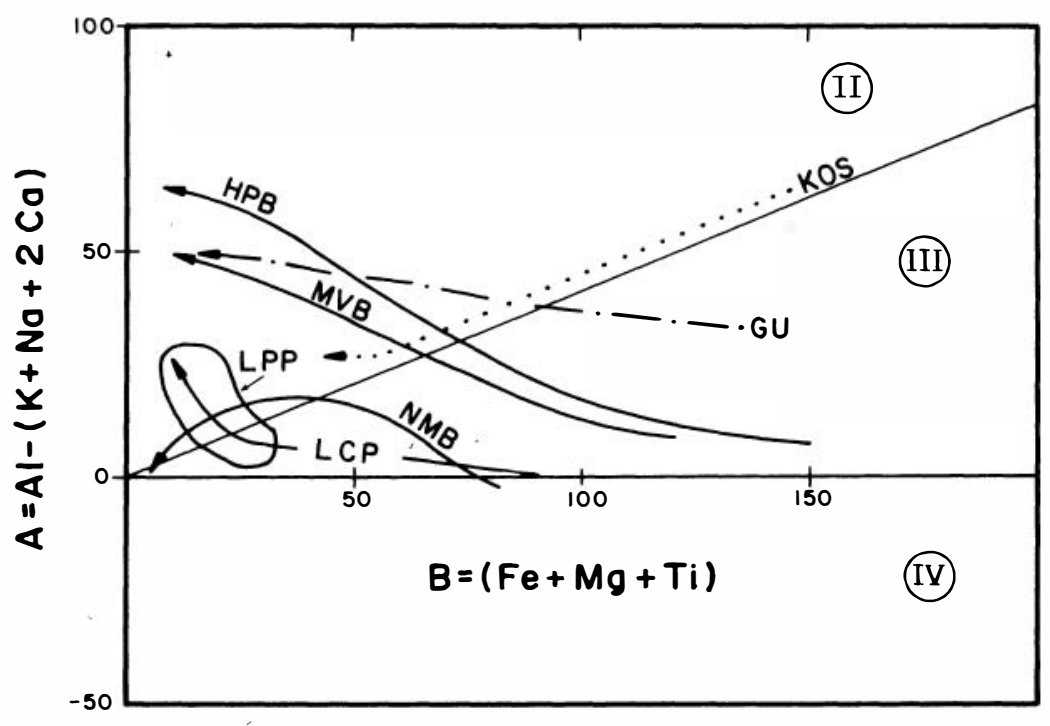

Fig. 2. A-B diagram after Debon \& Le Fort (1983) showing the general trends of PS (HPB and MVB) and PI (NMB, LCP and LPP) granites from Central Spain. For reference the Kosciusko (KOS) and Gueret (GU) trends (Debon \& Le Fort, 1983) are also shown. Others abbreviations as in Fig. 1. Fields II, III and IV after Debon \& Le Fort (1983). 
Table 1. Representative major (wt \%) and trace element (ppm) compositions of the Central Spain granites.

\begin{tabular}{|c|c|c|c|c|c|c|c|c|c|c|c|}
\hline \multirow[b]{2}{*}{ Sample } & \multicolumn{6}{|c|}{ PS Granites } & \multicolumn{5}{|c|}{ PI Granites } \\
\hline & $\begin{array}{l}77931^{3} \\
\text { MVB* }\end{array}$ & $\begin{array}{l}77928^{3} \\
\text { MVB* }\end{array}$ & $\begin{array}{l}79026^{3} \\
\text { MVB* }\end{array}$ & $\begin{array}{c}\text { EX-202 } \\
\text { ALP* }\end{array}$ & $\begin{array}{l}75674^{1} \\
\text { CDP* }\end{array}$ & $\begin{array}{l}\text { EX-5 } \\
\text { CMP* }\end{array}$ & $\begin{array}{c}\text { EX-12 } \\
\text { VP* }\end{array}$ & $\begin{array}{l}82967^{2} \\
\text { NMB* }^{*}\end{array}$ & $\begin{array}{l}87225^{4} \\
\text { LPP* }\end{array}$ & $\begin{array}{c}82717^{5} \\
\text { Peg* }\end{array}$ & $\begin{array}{l}57018^{5} \\
\text { LCP* }\end{array}$ \\
\hline $\mathrm{SiO}_{2}$ & 66.25 & 70.57 & 76.68 & 70.24 & 73.62 & 75.09 & 67.44 & 72.67 & 73.99 & 76.43 & 77.50 \\
\hline $\mathrm{TiO}_{2}$ & 0.64 & 0.37 & 0.03 & 0.36 & 0.18 & 0.13 & 0.62 & 0.27 & 0.14 & 0.05 & 0.05 \\
\hline $\mathrm{Al}_{2} \mathrm{O}_{3}$ & 15.77 & 15.49 & 13.56 & 14.77 & 14.04 & 13.03 & 15.18 & 13.92 & 13.38 & 12.92 & 12.62 \\
\hline $\mathrm{Fe}_{2} \mathrm{O}_{3}$ & 0.41 & 0.35 & 0.22 & $2.55^{\prime \prime}$ & $1.81^{*}$ & $1.41^{*}$ & $3.79^{\prime \prime}$ & 0.64 & 0.48 & 0.16 & 0.33 \\
\hline $\mathrm{FeO}$ & 3.73 & 2.28 & 0.63 & nd & nd & nd & nd & 1.61 & 1.24 & 0.82 & 0.55 \\
\hline $\mathrm{MnO}$ & 0.06 & 0.05 & 0.07 & 0.05 & 0.05 & 0.05 & 0.06 & 0.05 & 0.04 & 0.05 & 0.06 \\
\hline $\mathrm{MgO}$ & 1.42 & 0.72 & 0.03 & 0.61 & 0.50 & 0.12 & 1.19 & 0.54 & 0.29 & 0.10 & 0.03 \\
\hline $\mathrm{CaO}$ & 3.07 & 1.91 & 0.39 & 1.77 & 1.06 & 0.54 & 2.80 & 1.32 & 1.09 & 0.42 & 0.39 \\
\hline $\mathrm{Na}_{2} \mathrm{O}$ & 3.31 & 3.34 & 3.56 & 3.30 & 3.40 & 3.30 & 3.46 & 3.49 & 3.57 & 3.63 & 3.41 \\
\hline $\mathrm{K}_{2} \mathrm{O}$ & 3.98 & 4.22 & 4.38 & 4.12 & 4.65 & 4.71 & 3.96 & 4.45 & 4.80 & 4.58 & 4.48 \\
\hline $\mathrm{P}_{2} \mathrm{O}_{5}$ & 0.33 & 0.27 & 0.08 & 0.13 & 0.14 & 0.05 & 0.15 & 0.10 & 0.22 & 0.00 & 0.01 \\
\hline LOI & 0.73 & 0.92 & 0.57 & 0.86 & 0.71 & 0.50 & 0.73 & 0.31 & 0.58 & 0.76 & 0.82 \\
\hline Total & 99.70 & 100.48 & 100.21 & 98.76 & 100.17 & 98.93 & 99.38 & 99.37 & 99.82 & 99.92 & 100.25 \\
\hline C & 1.22 & 2.58 & 2.45 & 1.97 & 1.82 & 1.64 & 0.47 & 1.19 & 1.35 & 1.23 & 1.48 \\
\hline $\mathrm{Ba}$ & 684 & 425 & 1 & 478 & 291 & 73 & 491 & 367 & 329 & 40 & 19 \\
\hline $\mathrm{Rb}$ & 166 & 226 & 243 & 184 & 255 & 335 & 184 & 205 & 253 & 370 & 308 \\
\hline $\mathrm{Sr}$ & 168 & 139 & 10 & 139 & 85 & 24 & 162 & 75 & 46 & 10 & 10 \\
\hline Th & nd & nd & nd & 16 & nd & 14 & 21 & 14 & 22 & nd & 18 \\
\hline $\mathrm{Zr}$ & 224 & 172 & 60 & nd & nd & nd & nd & 140 & 121 & nd & 48 \\
\hline $\mathrm{Nb}$ & 18 & 19 & 5 & nd & nd & nd & nd & 13 & 15 & nd & 3 \\
\hline Y & 31 & 22 & 16 & 23 & nd & 29 & 31 & 34 & 77 & nd & 60 \\
\hline $\mathrm{La}$ & 43 & nd & 4 & 31 & nd & 14 & 41 & 10 & 28 & nd & 13 \\
\hline $\mathrm{Ce}$ & 85 & nd & 10 & 64 & nd & 31 & 79 & 37 & 53 & nd & 35 \\
\hline $\mathrm{Cr}$ & nd & nd & nd & $<10$ & $<10$ & $<10$ & 37 & nd & nd & nd & $<5$ \\
\hline $\mathrm{Ni}$ & 11 & 22 & 42 & $<10$ & $<10$ & $<10$ & $<10$ & nd & nd & nd & $<5$ \\
\hline
\end{tabular}

* Abbreviations as in figure 1. \# All $\mathrm{Fe}$ as $\mathrm{Fe}_{2} \mathrm{O}_{3}$. Data from:

1.-Brandebourger (1984); 2.-Casillas (1989); 3.-Andonaegui (1990); 4.-Pérez-S•ba (1991); 5.-This work.

Based on petrographic and geochemical data, two main granite types have been distinguished (Casillas, 1989). The first type is composed of cordierite-bearing granites, particularly in the most differentiated varieties. The best studied of these granites are the Hoyo de Pinares (Casillas, 1989) and Mora-Las Ventas batholiths (Andonaegui, 1990). The second type is characterized by the exclusive occurrence of biotite as a mafic phase, with the exception of scarce accessory amphibole in the marginal granodioritic facies, and rare accessory garnet (or exceptionally cordierite) in the most fractionated leucogranites. The most representative type is the Navas del Marqués batholith (Casillas, 1989), although there are other plutons that may be included in this group, i.e. La Cabrera (Bellido, 1979) and La Pedriza (Pérez-Soba, 1991) plutons (Fig. 1).

Peraluminosity of the two granite types is different as observed on the A-B diagram (Debon \& Le Fort, 1983) (Fig. 2). The first group of granites (PS) is clearly peraluminous whereas the second one (PI) yields subaluminous affinities ranging from metaluminous (typically the less evolved marginal facies), to moderately peraluminous granitoids in the more fractionated types. Peraluminosity of granites increases with acidity, contrasting with the classical variation showed by S-type granites. Nevertheless, the major element composition of the cordierite-bearing granites, hereafter called PS granites, is very sim- 
Table 2. Selected biotite analyses from Central Spain granites.

\begin{tabular}{|c|c|c|c|c|c|c|c|c|c|c|c|}
\hline \multicolumn{12}{|c|}{ PS Granites } \\
\hline Sample & $\begin{array}{c}77934^{3} \\
\text { MVB }\end{array}$ & $\begin{array}{c}77931^{3} \\
\text { MVB }\end{array}$ & $\begin{array}{c}77928^{5} \\
\text { MVB }\end{array}$ & $\begin{array}{l}80212^{3} \\
\mathrm{MVB}^{3} \\
\end{array}$ & $\begin{array}{c}79026^{3} \\
\mathrm{MVB}\end{array}$ & $\begin{array}{c}82421^{2} \\
\text { HPB }\end{array}$ & $\begin{array}{c}\text { EX199' } \\
\text { ALP }\end{array}$ & $\begin{array}{c}\mathrm{EX}^{202^{1}} \\
\text { ALP }\end{array}$ & $\begin{array}{c}75674^{5} \\
\mathrm{CDP} \\
\end{array}$ & $\begin{array}{l}\text { EX5 }{ }^{1} \\
\text { CMP }\end{array}$ & $\begin{array}{c}94719^{5} \\
\text { HMP }\end{array}$ \\
\hline $\mathrm{N}^{0}$ of data & 2 & 2 & 7 & 2 & 2 & 6 & 8 & 11 & 7 & 12 & 3 \\
\hline $\mathrm{SiO}_{2}$ & 36.27 & 34.41 & 34.24 & 35.07 & 34.74 & 35.01 & 35.27 & 34.72 & 35.14 & 34.58 & 34.44 \\
\hline $\mathrm{TiO}_{2}$ & 4.29 & 4.15 & 3.85 & 3.13 & 1.84 & 2.74 & 3.28 & 2.87 & 2.96 & 2.40 & 1.10 \\
\hline $\mathrm{Al}_{2} \mathrm{O}_{3}$ & 16.43 & 17.94 & 18.60 & 20.50 & 20.98 & 20.40 & 18.23 & 19.54 & 19.79 & 19.85 & 20.33 \\
\hline $\mathrm{FeO}_{\mathrm{t}}$ & 21.27 & 21.05 & 21.78 & 22.00 & 26.88 & 21.64 & 19.03 & 19.64 & 21.42 & 23.18 & 26.63 \\
\hline $\mathrm{MnO}$ & 0.27 & 0.16 & 0.30 & 0.40 & 1.99 & 0.48 & 0.23 & 0.45 & 0.48 & 0.87 & 1.36 \\
\hline $\mathrm{MgO}$ & 8.15 & 6.77 & 6.47 & 5.77 & 1.56 & 6.73 & 8.44 & 7.12 & 6.05 & 3.78 & 2.31 \\
\hline $\mathrm{CaO}$ & 0.00 & 0.00 & 0.03 & 0.00 & 0.00 & 0.02 & 0.01 & 0.01 & 0.04 & 0.00 & 0.05 \\
\hline $\mathrm{Na}_{2} \mathrm{O}$ & 0.07 & 0.21 & 0.22 & 0.18 & 0.04 & 0.13 & 0.21 & 0.27 & 0.16 & 0.14 & 0.05 \\
\hline $\mathrm{K}_{2} \mathrm{O}$ & 9.72 & 9.23 & 9.77 & 9.18 & 9.03 & 9.65 & 9.00 & 9.12 & 9.62 & 9.16 & 9.07 \\
\hline Total & 96.46 & 93.90 & 95.26 & 96.21 & 97.04 & 96.80 & 93.71 & 93.74 & 95.66 & 93.95 & 95.36 \\
\hline \multicolumn{12}{|c|}{ Number of ions on the basis of $22(0)$} \\
\hline $\mathrm{Si}$ & 5.509 & 5.365 & 5.303 & 5.333 & 5.381 & 5.302 & 5.434 & 5.372 & 5.383 & 5.432 & 5.412 \\
\hline $\mathrm{Al}^{\mathrm{NV}}$ & 2.491 & 2.635 & 2.697 & 2.667 & 2.619 & 2.698 & 2.566 & 2.628 & 2.617 & 2.568 & 2.588 \\
\hline $\mathrm{Al}^{\mathrm{vI}}$ & 0.450 & 0.662 & 0.698 & 1.006 & 1.211 & 0.943 & 0.745 & 0.936 & 0.956 & 1.109 & 1.179 \\
\hline $\mathrm{Ti}$ & 0.490 & 0.487 & 0.448 & 0.357 & 0.214 & 0.313 & 0.380 & 0.334 & 0.341 & 0.283 & 0.130 \\
\hline $\mathrm{Fe}^{3+}$ & 0.117 & 0.122 & 0.093 & 0.073 & 0.130 & 0.065 & 0.134 & 0.109 & 0.072 & 0.138 & 0.231 \\
\hline $\mathrm{Fe}^{2+}$ & 2.585 & 2.625 & 2.729 & 2.724 & 3.352 & 2.677 & 2.318 & 2.434 & 2.672 & 2.908 & 3.270 \\
\hline $\mathrm{Mn}$ & 0.034 & 0.020 & 0.039 & 0.051 & 0.261 & 0.061 & 0.030 & 0.059 & 0.062 & 0.115 & 0.181 \\
\hline $\mathrm{Mg}$ & 1.854 & 1.573 & 1.494 & 1.308 & 0.359 & 1.517 & 1.939 & 1.644 & 1.381 & 0.885 & 0.541 \\
\hline $\mathrm{Ca}$ & 0.000 & 0.000 & 0.005 & 0.000 & 0.000 & 0.004 & 0.001 & 0.002 & 0.000 & 0.000 & 0.009 \\
\hline $\mathrm{Na}$ & 0.021 & 0.064 & 0.064 & 0.052 & 0.011 & 0.038 & 0.063 & 0.081 & 0.047 & 0.044 & 0.016 \\
\hline $\mathrm{K}$ & 1.884 & 1.836 & 1.930 & 1.781 & 1.783 & 1.866 & 1.768 & 1.800 & 1.879 & 1.835 & 1.818 \\
\hline $\mathrm{XFe}$ & 0.584 & 0.625 & 0.646 & 0.676 & 0.903 & 0.638 & 0.545 & 0.597 & 0.660 & 0.767 & 0.858 \\
\hline $\mathrm{XMn}$ & 0.013 & 0.008 & 0.014 & 0.018 & 0.072 & 0.022 & 0.013 & 0.024 & 0.023 & 0.038 & 0.052 \\
\hline
\end{tabular}

ilar to the less peraluminous S-types (Dalgety suite of Chappell et al., 1991). The plutons with subaluminous characters, hereafter called PI granites, are related to I-type suites. Other chemical difference between the two main groups are lower $\left({ }^{87} \mathrm{Sr} /{ }^{86} \mathrm{Sr}\right)_{i}$ and higher $\mathrm{Ca}, \mathrm{Sr}$ and LREE within the PI granites (Villaseca et al., 1993). A high degree of oxidation in the PI types is also observed as common in the less peraluminous series in other sectors (White \& Chappell, 1988; Lalonde \& Bernard, 1993).

Representative chemical analyses of the two granite types are given in Table 1 .

It is important to note that these two granite types, very common in the European Hercynian belt (Pitcher, 1983) are essentially equivalent to other contrasting granite-types described in other collisional orogenic are as: I/S-types, allanite /monazite-bearing types or Cci/Hlo types (Chappell \& White, 1974; Barbarin, 1990).

\section{3.- Mineral chemistry}

\section{Analytical methods}

Chemical analyses of the mineral phases were made using a Camebax electron microprobe at the University of Nancy I (France) and at the Blaise Pascal University - C.N.R.S., U.R.A. nº 10 of Clermont-Ferrand (France). Most of the data were compiled from published works (Brandebourger, 1984; Casillas, 1989; Andonaegui, 1990; Pérez-Soba, 1991). Additional analyses (around 250) have been made in order to have a complete data set for the various granites.

About six hundred chemical analysis have been processed using the MINFILE program of Afifi \& Essene (1988). We have calculated structural formulae of the different phases and $\mathrm{Fe}^{3+}$ estimation by charge balance. $\mathrm{Fe}^{3+}$ in biotites has been estimated by two more specific methods: an iterative normalization after Dymek (1983) and the empirical method after Bruiyn et al. (1983). 
Table 2. Continuation.

\begin{tabular}{|c|c|c|c|c|c|c|c|}
\hline \multicolumn{8}{|c|}{ PI Granites } \\
\hline Sample & $\begin{array}{c}\mathrm{EX}-12^{\prime} \\
\vee \mathrm{P}\end{array}$ & $\begin{array}{c}77087^{2} \\
\text { NMB }\end{array}$ & $\begin{array}{c}82967^{2} \\
\text { NMB }\end{array}$ & $\begin{array}{c}87225^{4} \\
\text { LPP }\end{array}$ & $\begin{array}{c}82717^{5} \\
\text { Peg }\end{array}$ & $\begin{array}{c}57018^{5} \\
\text { LCP }\end{array}$ & $\begin{array}{c}95253^{5} \\
\text { LCP }\end{array}$ \\
\hline $\mathrm{N}^{0}$ of data & 10 & 4 & 6 & 1 & 5 & 3 & 5 \\
\hline $\mathrm{SiO}_{2}$ & 36.46 & 36.16 & 35.70 & 35.03 & 35.08 & 33.34 & 33.79 \\
\hline $\mathrm{TiO}_{2}$ & 3.89 & 3.17 & 3.56 & 2.96 & 1.34 & 1.87 & 1.84 \\
\hline $\mathrm{Al}_{2} \mathrm{O}_{3}$ & 13.81 & 15.51 & 15.09 & 16.88 & 19.73 & 18.39 & 18.79 \\
\hline $\mathrm{FeO}_{1}$ & 21.28 & 25.03 & 25.53 & 26.75 & 27.58 & 27.58 & 28.77 \\
\hline $\mathrm{MnO}$ & 0.27 & 0.35 & 0.56 & 0.90 & 0.92 & 1.21 & 2.11 \\
\hline $\mathrm{MgO}$ & 9.49 & 7.80 & 6.72 & 3.57 & 1.54 & 2.19 & 1.25 \\
\hline $\mathrm{CaO}$ & 0.01 & 0.04 & 0.02 & 0.00 & 0.06 & 0.16 & 0.00 \\
\hline $\mathrm{Na}_{2} \mathrm{O}$ & 0.06 & 0.06 & 0.04 & 0.10 & 0.03 & 0.05 & 0.00 \\
\hline $\mathrm{K}_{2} \mathrm{O}$ & 9.22 & 9.43 & 9.68 & 9.51 & 9.45 & 8.48 & 8.89 \\
\hline Total & 94.49 & 97.54 & 96.90 & 95.70 & 95.74 & 93.27 & 95.44 \\
\hline \multicolumn{8}{|c|}{ Number of ions on the basis of $22(\mathrm{O})$} \\
\hline $\mathrm{Si}$ & 5.640 & 5.507 & 5.513 & 5.511 & 5.509 & 5.392 & 5.379 \\
\hline $\mathrm{Al}^{\mathrm{N}}$ & 2.360 & 2.493 & 2.487 & 2.489 & 2.491 & 2.608 & 2.619 \\
\hline $\mathrm{Al}^{\mathrm{VI}}$ & 0.157 & 0.291 & 0.261 & 0.640 & 1.162 & 0.896 & 0.910 \\
\hline $\mathrm{Ti}$ & 0.453 & 0.363 & 0.414 & 0.351 & 0.158 & 0.227 & 0.217 \\
\hline $\mathrm{Fe}^{3+}$ & 0.281 & 0.303 & 0.283 & 0.260 & 0.241 & 0.340 & 0.248 \\
\hline $\mathrm{Fe}^{2+}$ & 2.472 & 2.885 & 3.016 & 3.260 & 3.382 & 3.392 & 3.579 \\
\hline $\mathrm{Mn}$ & 0.035 & 0.045 & 0.073 & 0.122 & 0.123 & 0.166 & 0.300 \\
\hline $\mathrm{Mg}$ & 2.819 & 1.770 & 1.548 & 0.843 & 0.361 & 0.528 & 0.298 \\
\hline $\mathrm{Ca}$ & 0.001 & 0.006 & 0.003 & 0.000 & 0.011 & 0.027 & 0.000 \\
\hline $\mathrm{Na}$ & 0.019 & 0.017 & 0.012 & 0.031 & 0.008 & 0.015 & 0.000 \\
\hline $\mathrm{K}$ & 1.820 & 1.832 & 1.909 & 1.910 & 1.893 & 1.750 & 1.810 \\
\hline $\mathrm{XFe}$ & 0.530 & 0.620 & 0.661 & 0.801 & 0.904 & 0.865 & 0.919 \\
\hline $\mathrm{XMn}$ & 0.014 & 0.015 & 0.024 & 0.040 & 0.035 & 0.047 & 0.088 \\
\hline
\end{tabular}

Both gave similar $\mathrm{Fe}^{3+}$ contents generally $<20 \%$ of the total iron. These results are consistent with those obtained by wet chemical methods on separated micas from very similar granitetypes (Alburquerque, 1973; Czamanske et al., 1981; De Pieri \& Jobstraibizer, 1983).

Abbreviations are those of Kretz (1983).

\section{Biotite}

The coloured mica is the main peraluminous and ferromagnesian mineral phase in these Hercynian granites. Chemically it is biotite s. s. with $\mathrm{X}_{\mathrm{Fe}}$ always higher than 0.50 (Table 2).

Although in several granitoids, different generations of biotite can be observed, we have selected the euhedral groundmass biotite with red to brown pleochroism, that is rich in accessory mineral inclusions, and is in contact with the main rock-forming minerals. In all cases we have avoided the late recrystallized mica displaying interstitial texture and pale to greenish colours, that is probably due to retrogressive episodes.
Biotite has been used as an index mineral to discriminate granite types in which it appears (Nockolds, 1947; Nachit et al., 1985; Lalonde \& Bernard, 1993). The major chemical distinguishing features of biotite of the two granite types considered here are: 1) - the total aluminium

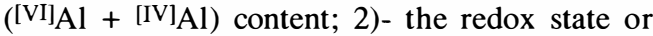
$\mathrm{Fe}^{3+} /\left(\mathrm{Fe}^{3+}+\mathrm{Fe}^{2+}\right)$ ratio; and 3$)-$ the $\mathrm{Na}$ content.

Biotite within PS granites is more peraluminous than within PI types and plots in the alumino-potassic field in the diagram of Fig. 3B. The difference in biotite peraluminosity is particularly evident in the more magnesian mica but is very slight to nonexistent in the iron-rich one. In the PI granites, the less aluminous biotites show slightly higher Si content (Fig. 5). Contents and variation trends in iron, magnesium and titanium are very similar in both granite-types with sub-parallel paths in several diagrams.

Biotite within PI granites is slightly $\mathrm{Fe}^{3+}$-enriched with respect $\mathrm{PS}$ granites. $\mathrm{Fe}^{3+} /\left(\mathrm{Fe}^{3+}+\mathrm{Fe}^{2+}\right)$ ratio is close to 0.10 in PI types while in PS is 

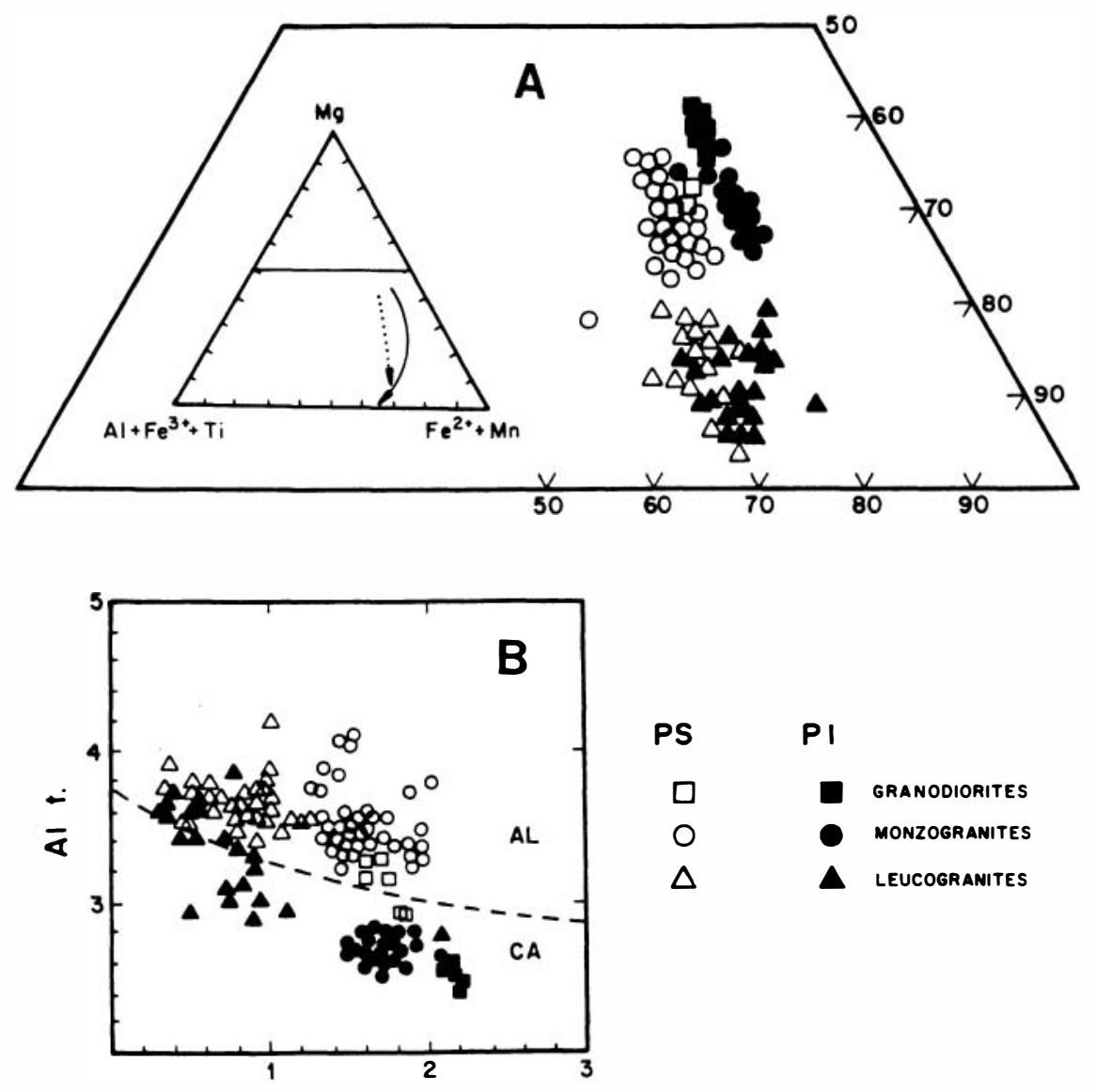

Mg

Fig. 3. Compositional diagrams for biotite of Central Spain granites. A) Relationship between octahedral cations of biotite; inset diagram shows the general trend of PS (dotted line) and PI (full line) granite biotites. $\mathrm{B}$ ) $\mathrm{Al}_{\mathbf{t}}-\mathrm{Mg}$ diagram with alumino-potassic (AL) and calc-alkaline (CA) fields after Nachit et al., (1985). Open symbols refer to PS granites, full symbols to PI granites. These and the following figures are based on atomic proportions unless otherwise noted.

around 0.05 (see Table 2). The compiled data of this study are consistent with $\mathrm{fO}_{2}$ conditions close to the QFM buffer for PS granite biotites while PI types are closer to the NNO buffer, which coincides with the general tendency of more reduced conditions in granites with higher peraluminosity index (Whalen \& Chappell, 1988; Lalonde \& Bernard, 1993). In both granite groups biotite becomes increasingly Fe-rich with falling temperature (or progressive crystallization) which is typical of reducing trends in terms of oxygen fugacity (Wones \& Eugster, 1965), and ilmenite-series (Czamanske et al.,
1981). It is also noticeable that the biotite $\mathrm{Fe} /(\mathrm{Fe}$ $+\mathrm{Mg}$ ) ratio is similar in both granitic series as opposed to other regions (Whalen \& Chappell, 1988; Speer, 1981; Lalonde \& Bernard, 1993) which could be consequence of the more complete sequence of plutonic types considered here, and also of the absence of metamorphic recrystallization processes overprinted as ocurr in other sectors.

Biotite within PS granites is also richer in $\mathrm{Na}$ than those within PI granites, which is more evident again in the more magnesian varieties, as the iron-rich members are depleted in $\mathrm{Na}$ (Fig. 5). 


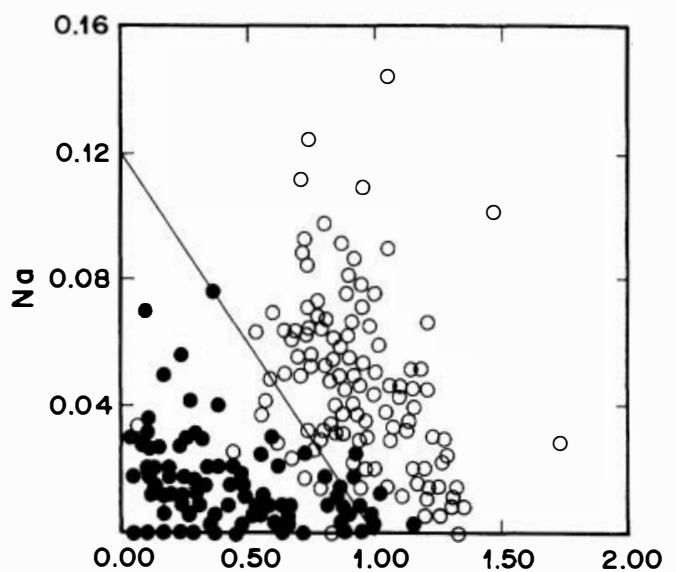

Al VI

Fig. 4. $\mathrm{Na}^{-}{ }^{[\mathrm{VI}]} \mathrm{Al}$ diagram for biotites of PI and PS granitic types of the Spanish Central Region. Full circles $=$ PI types; Open circles $=$ PS types .

Our data at this respect point to the potential of the $\mathrm{Na} / \mathrm{Al}$ ratio in biotite as a good discriminating feature of peraluminous granite series (Fig. 4). A consequence is that biotite within PS granites has a higher $\mathrm{Na} / \mathrm{K}$ ratio, as was noticed by Nockolds (1947).

The chemical variability of biotite and the correlation between some elements are similar in the two granitic types. Thus, there is an increase in [VI] $\mathrm{Al}$ and $\mathrm{Mn}$ and a decrease in $\mathrm{Mg}$ and $\mathrm{Ti}$ with the increase in the $\mathrm{Fe}^{2+} /\left(\mathrm{Mg}+\mathrm{Fe}^{2+}\right)$ ratio (Fig. 5). Contents of the other elements, particularly in the tetrahedral site $\left(\mathrm{Si},{ }^{[\mathrm{IV}]} \mathrm{Al}\right)$ and some interlayered cations $(\mathrm{K}, \mathrm{Ca})$, are more or less constant.

The increase in the ${ }^{[\mathrm{VI}]} \mathrm{Al}$ does not have any

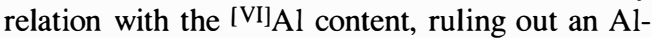
Tschermak substitution mechanism (Speer \& Becker, 1992). The good correlation between Ti,

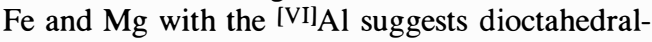
trioctahedral mica substitution.

An increase in the $\mathrm{Mn}$ content with $\mathrm{X}_{\mathrm{Fe}}$ is clearly defined (Fig. 5) in contrast with other granitic types where it is not observed (De Pieri \& Jobstraibizer, 1983). The high Mn content of biotite and other companion mafic phases is typical of peraluminous granites, although also shown by other granitic series with calc-alkaline affinities (Czamanske et al., 1981).

Biotites of the evolved granites do not show clear correlation between $\mathrm{Fe}^{3+}$ and $\mathrm{Fe}^{2+}$ content, although there is an increase in the total iron con- tent, perhaps with the exception of some fractionated PI granites where a positive correlation between $\mathrm{Fe}^{2+}$ and $\mathrm{Fe}^{3+}$ can be observed. This is not shown by biotites from other plutonic rocks (De Pieri \& Jobstraibizer, 1983). There is a slight increase in the $\mathrm{Fe}^{3+} / \mathrm{Fe}^{2+}$ with the $\mathrm{X}_{\mathrm{Fe}}$ in the PS granite biotites that is not clearly shown by the PI granites. Divergent trends could be evidenced in the most PI granites (see Fig. 7 below) leading to either more oxidized (La Pedriza and Las Navas del Marqués plutons) and less oxidized (La Cabrera, Peguerinos) rocks. In this respect, it is important to note that magnetite is associated with the more oxidized biotites in one of the PI plutons (La Pedriza, Pérez-Soba, 1991).

The decrease in $\mathrm{Na}$ content in PS granite biotites must be related to the $\mathrm{K}$ content or with other interlayered cations as other authors presume (Dymek, 1983). The behaviour of $\mathrm{K}$ is complex. It shows a slight tendency to increase until $\mathrm{X}_{\mathrm{Fe}}$ in the biotite reaches about 0.65 then to decrease above this value (Fig. 5). This is better shown by PS granites as a consequence of their $\mathrm{K}$-deficiency in the $\mathrm{Mg}$-richer biotites.

\section{Cordierite}

Cordierite is an accessory mineral phase in several facies of the PS granites. Only in one PI pluton (La Cabrera) does cordierite appear forming nodules in the most fractionated leucogranites (Bellido, 1979). Textural and compositional features indicate magmatic origin and conflict with the hypothesis of xenolithic derivation or assimilation process as previously proposed (Aparicio et al., 1975).

In the PS granites, cordierite is usually subhedral, inclusion-free, and rarely interstitial. It appears dispersed in the whole plutonic body, without any spatial relation to marginal or contaminated xenolith-rich facies. Thus, field evidence of significant assimilation is lacking and a late crystallization origin is suggested (Abbott \& Clarke, 1979; Shimura et al., 1992). Cordieritequartz intergrowths showing micrographic textures of clear igneous origin and indicating a late crystallization stage occur in the highly differentiated aplo-pegmatitic facies .

Cordierite of the La Cabrera pluton (the only PI-type with this phase) has a lower content in $\mathrm{Al}_{2} \mathrm{O}_{3}$ and alkalies, especially $\mathrm{Na}$ (Table 3) than cordierites of the PS types with similar $\mathrm{X}_{\mathrm{Fe}}$. The lower content in $\mathrm{Al}$ can be explained by the sub- 


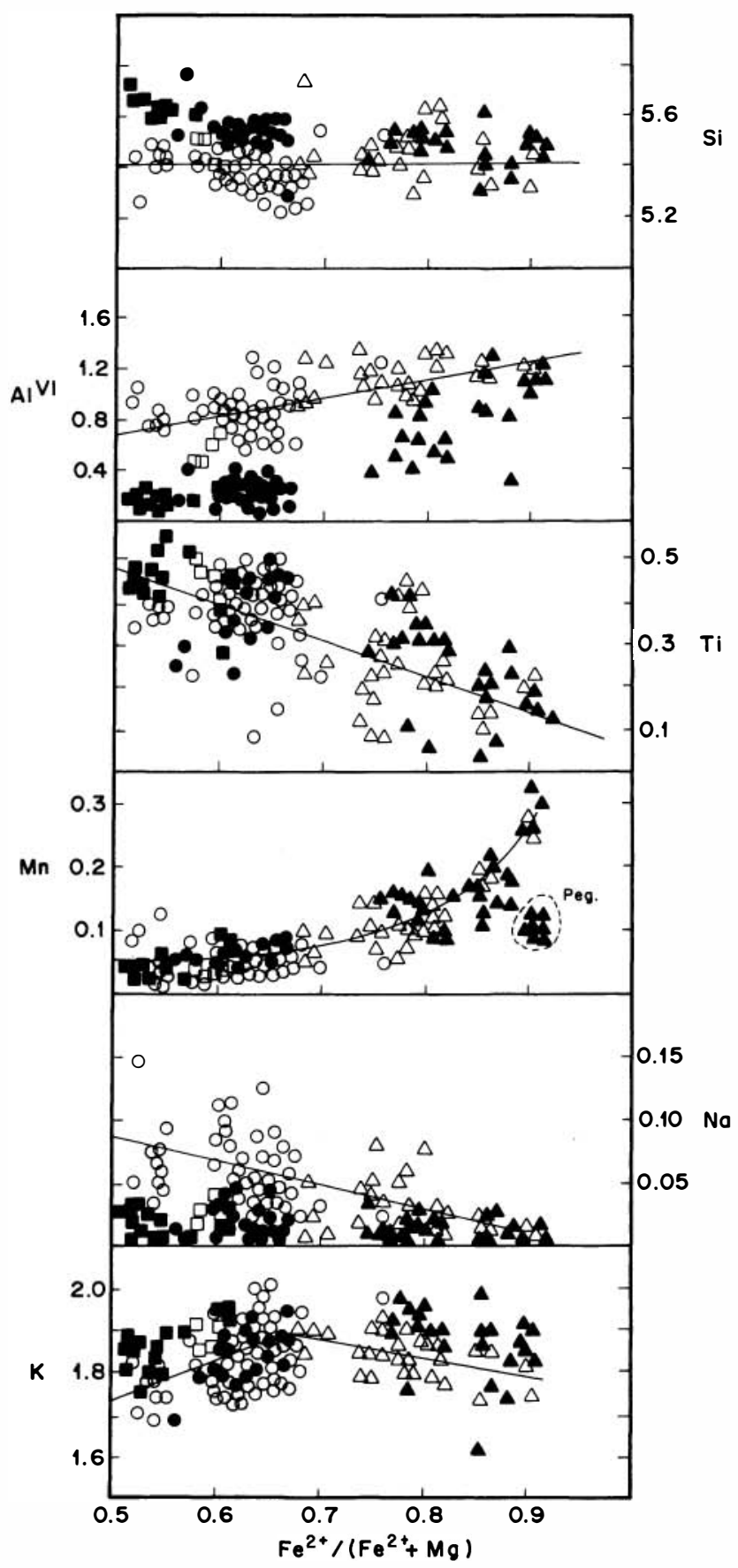

Fig. 5. $\mathrm{Si}$, ${ }^{[\mathrm{VI}]} \mathrm{Al}, \mathrm{Ti}, \mathrm{Mn}, \mathrm{Na}$ and $\mathrm{K}$ variation diagrams with $\mathrm{Fe}^{2+} /\left(\mathrm{Fe}^{2+}+\mathrm{Fe}^{3+}\right)$ as differentiation index for biotite of PS and PI granites. Evolutionary trend for PS granites biotites is also shown. Peg = Peguerinos pluton biotites. Same symbols as in Fig. 3. 
Table 3. Selected cordierite analyses from Central Spain granites.

\begin{tabular}{|c|c|c|c|c|c|c|c|}
\hline \multicolumn{7}{|c|}{ PS Granites } & \multirow{2}{*}{$\begin{array}{c}\text { PI } \\
57018^{5} \\
\text { LCP }\end{array}$} \\
\hline Sample & $\begin{array}{c}77928^{5} \\
\text { MVB }\end{array}$ & $\begin{array}{c}79026^{3} \\
\text { MVB }\end{array}$ & $\begin{array}{c}82421^{2} \\
\text { HPB }\end{array}$ & $\begin{array}{c}\text { EX202' } \\
\text { ALP }\end{array}$ & $\begin{array}{c}75674^{5} \\
\text { CDP }\end{array}$ & $\begin{array}{l}\text { EX5 }^{1} \\
\text { CMP }\end{array}$ & \\
\hline $\mathrm{N}^{0}$ of data & 6 & 8 & 2 & 10 & 10 & 6 & 4 \\
\hline $\mathrm{SiO}_{2}$ & 47.37 & 45.95 & 46.58 & 46.95 & 46.82 & 46.78 & 46.03 \\
\hline $\mathrm{TiO}_{2}$ & 0.03 & 0.02 & 0.03 & 0.00 & 0.01 & 0.02 & 0.02 \\
\hline $\mathrm{Al}_{2} \mathrm{O}_{3}$ & 32.34 & 31.78 & 32.19 & 32.17 & 32.01 & 31.78 & 30.14 \\
\hline $\mathrm{FeO}_{\mathrm{t}}$ & 10.20 & 13.93 & 11.33 & 9.91 & 10.20 & 12.43 & 14.52 \\
\hline $\mathrm{MnO}$ & 0.51 & 1.73 & 0.85 & 0.58 & 0.84 & 1.14 & 3.61 \\
\hline $\mathrm{MgO}$ & 6.27 & 1.43 & 4.81 & 5.84 & 4.87 & 3.12 & 0.80 \\
\hline $\mathrm{CaO}$ & 0.02 & 0.04 & 0.06 & 0.02 & 0.04 & 0.01 & 0.09 \\
\hline $\mathrm{Na}_{2} \mathrm{O}$ & 0.57 & 1.84 & 1.01 & 0.64 & 1.22 & 1.03 & 1.09 \\
\hline $\mathrm{K}_{2} \mathrm{O}$ & 0.03 & 0.03 & 0.03 & 0.01 & 0.01 & 0.05 & 0.02 \\
\hline Total & 97.34 & 96.75 & 96.88 & 96.14 & 96.02 & 96.35 & 96.31 \\
\hline \multicolumn{8}{|c|}{ Number of ions on the basis of $18(0)$} \\
\hline $\mathrm{Si}$ & 4.991 & 5.006 & 4.976 & 5.003 & 5.017 & 5.048 & 5.085 \\
\hline $\mathrm{Al}$ & 4.015 & 4.081 & 4.051 & 4.040 & 4.043 & 4.041 & 3.924 \\
\hline $\mathrm{Ti}$ & 0.002 & 0.001 & 0.002 & 0.000 & 0.001 & 0.001 & 0.001 \\
\hline $\mathrm{Fe}^{2+}$ & 0.899 & 1.270 & 1.012 & 0.883 & 0.914 & 1.121 & 1.342 \\
\hline $\mathrm{Mn}$ & 0.046 & 0.160 & 0.076 & 0.053 & 0.076 & 0.104 & 0.338 \\
\hline $\mathrm{Mg}$ & 0.985 & 0.232 & 0.766 & 0.928 & 0.777 & 0.502 & 0.132 \\
\hline $\mathrm{Ca}$ & 0.003 & 0.005 & 0.007 & .0 .002 & 0.004 & 0.001 & 0.011 \\
\hline $\mathrm{Na}$ & 0.116 & 0.389 & 0.209 & 0.133 & 0.254 & 0.215 & 0.233 \\
\hline K & 0.004 & 0.004 & 0.004 & 0.002 & 0.002 & 0.007 & 0002 \\
\hline $\mathrm{XFe}$ & 0.477 & 0.846 & 0.568 & 0.488 & 0.540 & 0.691 & 0.910 \\
\hline $\mathrm{XMn}$ & 0.048 & 0.112 & 0.071 & 0.056 & 0.077 & 0.085 & 0.201 \\
\hline
\end{tabular}

stitution of this cation by $\mathrm{Si}^{4+}$ in tetrahedral position.

In all cordierites $\mathrm{Fe}, \mathrm{Mn}$ and $\mathrm{Na}$ increase with increasing in silica content of host granite but there are no significative variations in $\mathrm{Al}, \mathrm{Ca}$ or $\mathrm{K}$. The slight decrease in Ti reflects that shown by the whole rocks and is attributed to magmatic differentiation. The high $\mathrm{Mn}$ and $\mathrm{Na}$ contents of cordierites make them different from those of metamorphic rocks (Miyashiro, 1957) and also from the restitic cordierites (Barbero \& Villaseca, 1992).

The high $\mathrm{Mn}$ content (up to $3 \% \mathrm{MnO}$ ) and $\mathrm{X}_{\mathrm{Fe}}$ values ( $\geq$ 0.84) (Andonaegui, 1990; Bellido, 1979 ) in cordierites of some leucogranites is noticeable. This feature is typical of cordierite from high-Si intrusives and has rarely been observed in previous works (Secchi et al., 1991). The estimation of $\mathrm{Fe}^{2+}$ by charge balance indicates all the iron is ferrous, as it is normal in $\mathrm{Mn}$ and alkali-rich cordierite (Gordillo et al., 1985).
There is a good positive correlation between the $\mathrm{Na}$ and $\mathrm{Mn}$ or Fe contents and also a negative correlation with $\mathrm{Mg}$ suggesting a substitution mechanism of $\mathrm{Na}^{+}+\left(\mathrm{Li}^{+} ?\right)=\mathrm{Mg}^{2+}$, as hinted by Gordillo et al. (1985) and Vry et al. (1990).

Alkali-rich cordierite presumably has high volatile contents and low $\mathrm{X}_{\mathrm{CO}_{2}}$ (generally $\leq 0.05$, Gordillo et al., 1985; Vry et al., 1990). The total sum of iron-rich cordierite analyses is around $97 \%$ (Table 3) which suggests volatile contents of 2-3\% (probably mainly $\mathrm{H}_{2} \mathrm{O}$ ) and/or the presence of $\mathrm{Li}$ or $\mathrm{Be}$ as observed in cordierites of highly fractionated magmas (Schreyer et al., 1979; Gordillo et al., 1985). Na- and Mn-rich cordierite (and also presumably rich in water) usually appears in the leucogranitic and aplo-pegmatitic facies in which it is enclosed within nodule structures with micro-pegmatitic intergrowth textures, normally with quartz and very similar to other tourmaline or mica nodules. These features suggest that the generation of cordierite nodules could be related 
Table 4. Selected garnet (core) analyses from Central Spain granites.

\begin{tabular}{|c|c|c|c|c|c|c|c|}
\hline \multicolumn{5}{|c|}{ PS Granites } & \multicolumn{3}{|c|}{ PI Granites } \\
\hline Sample & $\begin{array}{l}77928^{5} \\
\text { MVB }\end{array}$ & $\begin{array}{c}76394^{2} \\
\text { HPB }\end{array}$ & $\begin{array}{c}\mathrm{Pegm}^{2} \\
\mathrm{HPB}\end{array}$ & $\begin{array}{c}94719^{5} \\
\text { HMP }\end{array}$ & $\begin{array}{c}82717^{5} \\
\text { Peg }\end{array}$ & $\begin{array}{c}87281^{4} \\
\text { LPP }\end{array}$ & $\begin{array}{c}95253^{5} \\
\text { LCP }\end{array}$ \\
\hline Zoning & Type-I & - & - & Type-II & $\cdot$ & Type-III & Type-II \\
\hline $\mathrm{N}^{\circ}$ of data & 17 & 4 & 3 & 10 & 6 & 62 & 33 \\
\hline $\mathrm{SiO}_{2}$ & 37.52 & 38.39 & 36.94 & 35.77 & 36.78 & 36.57 & 35.34 \\
\hline $\mathrm{TiO}_{2}$ & 0.03 & 0.01 & 0.01 & 0.03 & 0.01 & 0.02 & 0.03 \\
\hline $\mathrm{Al}_{2} \mathrm{O}_{3}$ & 21.81 & 22.77 & 21.26 & 21.03 & 21.33 & 21.35 & 21.16 \\
\hline $\mathrm{FeO}_{4}$ & 31.23 & 32.93 & 34.61 & 14.13 & 32.18 & 26.66 & 15.23 \\
\hline $\mathrm{MnO}$ & 4.68 & 3.50 & 8.76 & 24.34 & 9.71 & 14.99 & 27.88 \\
\hline $\mathrm{MgO}$ & 4.57 & 4.47 & 0.54 & 0.17 & 0.21 & 0.09 & 0.05 \\
\hline $\mathrm{CaO}$ & 1.08 & 1.68 & 0.60 & 1.77 & 0.83 & 0.45 & 0.33 \\
\hline Total & 100.95 & 103.73 & 102.72 & 97.23 & 101.04 & 100.12 & 100.02 \\
\hline \multicolumn{8}{|c|}{ Number of ions on the basis of $24(0)$} \\
\hline $\mathrm{Si}$ & 5.934 & 5.906 & 5.938 & 5.990 & 5.980 & 5.990 & 5.853 \\
\hline $\mathrm{Al}^{\mathrm{N}}$ & 0.066 & 0.101 & 0.062 & 0.037 & 0.035 & 0.025 & 0.147 \\
\hline $\mathrm{Al}^{\mathrm{VI}}$ & 4.000 & 4.027 & 3.967 & 4.113 & 4.052 & 4.097 & 3.983 \\
\hline $\mathrm{Ti}$ & 0.004 & 0.001 & 0.002 & 0.003 & 0.001 & 0.002 & 0.004 \\
\hline $\mathrm{Mg}$ & 1.077 & 1.025 & 0.130 & 0.043 & 0.052 & 0.022 & 0.012 \\
\hline $\mathrm{Fe}^{2+}$ & 4.131 & 4.236 & 4.653 & 1.978 & 4.376 & 3.651 & 2.109 \\
\hline $\mathrm{Mn}$ & 0.627 & 0.456 & 1.192 & 3.451 & 1.337 & 2.079 & 3.911 \\
\hline $\mathrm{Ca}$ & 0.183 & 0.277 & 0.103 & 0.317 & 0.144 & 0.079 & 0.059 \\
\hline Alm & 68.64 & 70.68 & 76.55 & 34.16 & 74.06 & 62.60 & 34.63 \\
\hline Grs & 3.04 & 4.62 & 1.70 & 5.47 & 2.44 & 1.35 & 0.96 \\
\hline Prp & 17.90 & 17.07 & 2.13 & 0.74 & 0.87 & 0.37 & 0.20 \\
\hline Sps & 10.42 & 7.62 & 19.62 & 59.63 & 22.63 & 35.68 & 64.21 \\
\hline $\mathrm{XFe}$ & 0.793 & 0.805 & 0973 & 0.979 & 0.988 & 0.994 & 0.994 \\
\hline $\mathrm{XMn}$ & 0.132 & 0.100 & 0.204 & 0.636 & 0.234 & 0.363 & 0.650 \\
\hline
\end{tabular}

to an aqueous volatile segregation in highly fractionated peraluminous liquids that could stabilize the growth of cordierite, as it has been suggested for the formation of similar nodules in granitoids (Holub et al., 1981).

\section{Garnet}

Garnet is an occasional accessory phase in some plutons considered here. It can appear either in certain lithologies of PS granites (garnet-types I and II) or in some felsic facies of highly evolved PI granites (garnet-types II and III). We recognize three different garnet types:

- Type-I garnet occurs in the main facies of some PS monzogranites (Hoyo de Pinares, MoraLas Ventas plutons), dispersed in the least fractionated (granodioritic) plutonic facies. Garnet occurrs as inclusions in plagioclase or as small crystals showing reaction rims of cordierite, biotite and minor spinel. On this ground it has been interpreted as restitic mineral (Casillas, 1989; Andonaegui, 1990).

- Type-II garnet is found in the leucocratic facies of the PS or PI batholiths and exceptionally can be present in the cordierite nodular facies of PS leucogranites. As for type-I garnet it is not spatially related to xenoliths or border facies; by contrast it is in textural equilibrium with other mineral phases of the granite, and its small size, subhedral form or micrographic intergrowth with quartz, are suggestive of a relatively late-magmatic origin.

- Finally, type-III garnet occurs in the PI leucogranites, showing textures similar to those of the subhedral type-II garnets. It seems reasonable to suppose that type-II and III garnets are both of late-magmatic origin.

The chemistry of the garnets is summarized on Table 4. In terms of Alm-Pyr-Sps contents they show two clearly different compositions. Type-I garnet is essentially Alm-Pyr and their spessar- 
tine component is usually not greater than $10 \%$ in molar fraction. Types-II and -III garnets of the more acid granites are solid solutions of mainly almandine and spessartine and rarely is their pyrope content greater than $3 \%$ in molar fraction. Type-II garnet shows the highest Mn content (spessartine content greater than $60 \%$ ). The good correlation between the garnets and the host rock composition confirms a magmatic origin.

Each garnet type is characterized by a peculiar chemical zoning (Fig. 6). The type-I show a normal zoning marked by a decrease in pyrope content toward the rim. Grossular content is constant and spessartine content tends to show an oscillatory path, although the data are scarce. Their compositional profiles have a characteristic central flat zone and a re-equilibrated rim (Fig. 6).

Type-II garnet displays a complex zoning path with an oscillatory character (Fig. 6). There is an antithetic variation in almandine and grossularspessartine, the pyrope content being relatively constant from core to rim. This oscillatory zoning is occasionally observed in highly fractionated leucogranites (Pierrel, 1987), and a retrograde or secondary origin can be ruled out, taking into consideration that there is no textural evidence for such a process and the fact that no $\mathrm{Mn}$ increase or $\mathrm{Mg}-\mathrm{Ca}$ decrease toward the rim was observed. The high Mn content of this garnet implies crystallization at lower temperature that prevents the internal homogeneization during growth (Spear, 1991).

Type-III garnet shows the reverse zoning typical of this mineral in weakly peraluminous leucogranites (Du Bray, 1988), with the maximun almandine content in the core and an enrichment in the spessartine molecule toward the rim (Fig. 6). The pyrope content is very low and almost zero in the border.

Only the type-III garnet has a typical igneous zonation pattern, reflecting increase in the $\mathrm{Mn} /(\mathrm{Fe}+\mathrm{Mg})$ molar ratio within the magma during the cooling process and associated progressive fractional crystallization (Clarke, 1981; Abbot, 1981). Nevertheless, normal zoning (Ligget, 1990) and complex/oscillatory zoning patterns (Pierrel, 1987) are considered to be of magmatic origin, sometimes in pegmatitichydrothermal environments.

The garnet chemical evolution is comparable with that observed in other ATFM mineral phases considered here, i.e. biotite and cordierite. In garnet $\mathrm{Fe} /(\mathrm{Fe}+\mathrm{Mg})$ ratio and the $\mathrm{Mn}$ content increases with progressive differentiation whereas the $\mathrm{Mg}$ and, to a lesser degree the $\mathrm{Ca}$ contents tends to decrease.

The increase in Mn content could be not only related to magma cooling, but also to different hydration conditions (Robinson, 1991), which could be diverse in highly fractionated acid magmas.
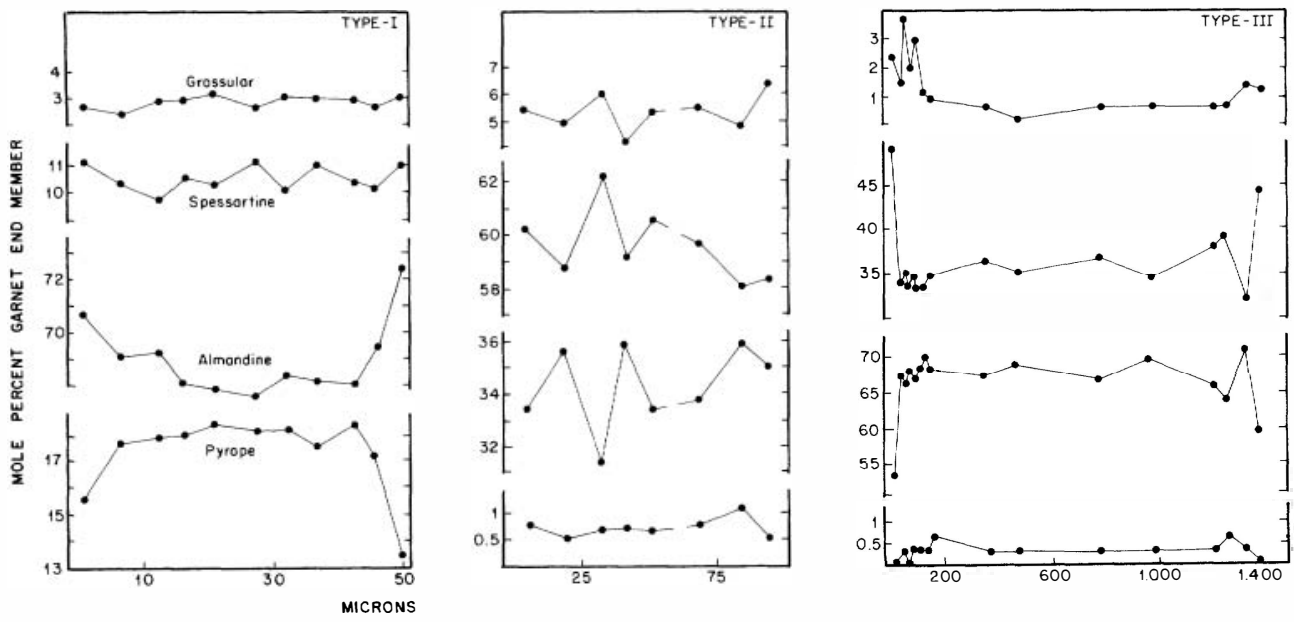

Fig. 6. Rim to rim profiles of three garnet types from Central Spain granites. The type II-garnet profile is made with two partial core to rim sections from adjacent grains. Type III-garnet is redrawn from Pérez-Soba (1991) data. 
In general, the grossular component of the igneous garnet tends to decrease within the most acid magmas, and this is shown in both calc-alkaline series and on I-S granitoids (Green, 1992). Some authors (Speer \& Becker, 1992) evidence increases in grossular and spessartine molecules toward garnet rim. This can be observed in some of the studied leucogranites (Fig. 6). The enrichment in grossular molecule in some garnets of the aplo-pegmatitic facies cannot be easily explained as a consequence of subsolidus plagioclase breakdown as has been proposed by some authors (Du Bray, 1988) because there is no textural evidence of such a process. It should be recalled that the grossular proportion increases with increasing $\mathrm{H}_{2} \mathrm{O}$ content in magmas (Green, 1992).

\section{Aluminium silicates}

The most abundant $\mathrm{Al}_{2} \mathrm{SiO}_{5}$ polymorph in the studied peraluminous granites is andalusite, although occasionally sillimanite has been found (Aparicio et al., 1975). Andalusite is particularly abundant in the PS acid types with accessory cordierite. The andalusite is also found in the garnet-bearing facies of these granite types.

Andalusite could be a late-magmatic mineral in high-silica magmas. A lower solidus temperature and higher volatile contents could allow crystallization of andalusite in residual liquids (Zen, 1988). Nevertheless in such a multipleintruded area as the Spanish Central Region it is very probable that part of the andalusite could be consequence of contact metamorphism (PérezSoba, 1991).

A restitic origin of the andalusite is unlikely, since its low pressure and temperature stability field (compared to the other aluminium silicate polymorphs) would make it unstable during anatectic conditions at intermediate melt fractions (biotite dehydration melting).

No significant chemical variation in the composition of the $\mathrm{Al}_{2} \mathrm{SiO}_{5}$ has been found. The calculations of $\mathrm{Kd}\left(=(\right.$ asill $) \mathrm{Al}_{2} \mathrm{SiO}_{5} /\left(\mathrm{a}_{\mathrm{And}}\right)^{\left.\mathrm{Al}_{2} \mathrm{SiO}_{5}\right)}$ after Kerrick \& Speer (1988) when andalusite and sillimanite co-exist gave values between 1.000 and 1.003 (Casillas, 1989; Pérez-Soba, 1991), very close to the equilibrium between the pure end-members.

\section{Fe-Ti oxide}

Ilmenite is the typical ore mineral in all the studied granites. It co-exists with magnetite in the marginal facies of La Pedriza pluton, a PI-type.

The study of ilmenite underscores the fact that peraluminous granites are usually low in oxide mineral content and in the more siliceous samples it is sometimes impossible to find any ilmenite grain in a thin section. In general, there is a close association of ilmenite with mafic silicates or plagioclase, supporting a magmatic origin. Although several generations and chemical variations of ilmenite have been found in other peraluminous granites (Czamanske et al., 1981; Pichavant et al., 1988) we have no conclusive data to offer for the granitoids studied here.

The chemical composition of ilmenites shows an evolutionary path comparable to the other ATFM phases considered (Table 5). The more differentiated the granite, the less $\mathrm{TiO}_{2}$ and $\mathrm{FeO}$ in the ilmenite, these cations being substituted by Mn (Table 5). The good correlation observed between $\mathrm{TiO}_{2}$ and $(\mathrm{Fe}+\mathrm{Mn})$ within ilmenite is mainly marked by the deficiency in divalent cations and a corresponding excess in $\mathrm{Ti}$, as has been noticed in peraluminous volcanic rocks (Pichavant et al., 1988). However, while in the aforementioned volcanic rocks the low chemical summation and the presence of $\mathrm{Fe}^{3+}$ within ilmenite indicates a probable retrograde origin, in the ilmenites of the granites considered here these chemical characteristics have not been observed and a magmatic origin for the observed chemical evolution of this mineral is highly probable, as has been also noticed in other plutons (Neiva et al., 1987).

The high $\mathrm{MnTiO}_{3}$ content in solid solution in ilmenites of some leucogranites (up to $30 \% \mathrm{~mol}$ ) is worth mentioning, although this value is much less than those found in the Macusani volcanics (Pichavant et al., 1988).

Pérez Soba (1991) reports magnetite crystals in La Pedriza pluton with exsolved ilmenite lamellae showing a compositional zoning pattern marked by an increase in $\mathrm{Mn}$ and $\mathrm{Ti}$ contents toward the crystal rim (core-rim $\mathrm{MnO}$ from 0.12 to $1.44 \%$; $\mathrm{TiO}_{2}$ from 0.22 to $5.00 \%$ ). This $\mathrm{MnO}$ increase agrees with the behaviour of this element during fractional crystallization of granitic magmas.

\section{Other minerals}

In some granodioritic-monzogranitic PI facies amphibole and more rarely clinopyroxene 
Table 5. Selected Fe-Ti oxide analyses from Central Spain granites.

\begin{tabular}{|c|c|c|c|c|c|c|c|c|c|}
\hline \multicolumn{6}{|c|}{ PS Granites } & \multicolumn{4}{|c|}{ PI Granites } \\
\hline Sample & $\begin{array}{l}77931^{5} \\
\text { MVB }\end{array}$ & $\begin{array}{c}86195^{2} \\
\text { HPB }\end{array}$ & $\begin{array}{c}\text { EX202 }^{\prime} \\
\text { ALP }\end{array}$ & $\begin{array}{c}75674^{5} \\
\text { CDP }\end{array}$ & EXY' & $\begin{array}{l}\text { EX12 }^{1} \\
\text { VP }\end{array}$ & $\begin{array}{c}82967^{2} \\
\text { NMB }\end{array}$ & $\begin{array}{c}86805^{4} \\
\text { LPP }\end{array}$ & $\begin{array}{c}85136^{4} \\
\text { LPP }\end{array}$ \\
\hline $\mathrm{N}^{o}$ of data & 1 & 1 & 13 & 3 & 3 & 4 & 1 & 1 & 2 \\
\hline $\mathrm{SiO}_{2}$ & 0.00 & 0.03 & 0.01 & 0.00 & 0.01 & 0.12 & 0.00 & 0.00 & 0.21 \\
\hline $\mathrm{TiO}_{2}$ & 52.92 & 53.64 & 52.33 & 52.80 & 51.43 & 51.24 & 53.14 & 52.21 & 0.08 \\
\hline $\mathrm{Al}_{2} \mathrm{O}_{3}$ & 0.00 & 0.04 & 0.00 & 0.02 & 0.02 & 0.00 & 0.00 & 0.03 & 0.21 \\
\hline $\mathrm{FeO}_{4}$ & 41.52 & 33.62 & 39.61 & 38.84 & 37.95 & 39.70 & 36.75 & 37.22 & 92.29 \\
\hline $\mathrm{MnO}$ & 3.76 & 14.51 & 4.52 & 8.68 & 6.93 & 6.02 & 9.74 & 12.12 & 0.17 \\
\hline $\mathrm{MgO}$ & 0.00 & 0.01 & 0.03 & 0.01 & 0.06 & 0.08 & 0.00 & 0.00 & 0.00 \\
\hline $\mathrm{CaO}$ & 0.00 & 0.06 & 0.00 & 0.03 & 0.00 & 0.06 & 0.00 & 0.06 & 0.00 \\
\hline Total & 98.20 & 101.91 & 96.50 & 100.39 & 96.40 & 97.22 & 99.72 & 101.64 & 92.96 \\
\hline \multicolumn{10}{|c|}{ Number of ions on the basis of $6(\mathrm{O})$ (ilmenite) or $4(\mathrm{O})$ (magnetite) } \\
\hline $\mathrm{Si}$ & 0.000 & 0.001 & 0.000 & 0.000 & 0.001 & 0.060 & 0.000 & 0.000 & 0.008 \\
\hline $\mathrm{Al}$ & 0.000 & 0.001 & 0.000 & 0.001 & 0.001 & 0.000 & 0.000 & 0.000 & 0.010 \\
\hline $\mathrm{Ti}$ & 2.030 & 2.000 & 2.040 & 1.996 & 2.016 & 1.992 & 2.010 & 1.962 & 0.002 \\
\hline $\mathrm{Fe}^{3+}$ & - & - & - & - & - & . & - & - & 1.970 \\
\hline $\mathrm{Fe}^{2+}$ & 1.771 & 1.391 & 1.717 & 1.633 & 1.654 & 1.726 & 1.552 & 1.561 & 1.004 \\
\hline $\mathrm{Mn}$ & 0.162 & 0.612 & 0.198 & 0.370 & 0.306 & 0.264 & 0.411 & 0.510 & 0.006 \\
\hline $\mathrm{Mg}$ & 0.000 & 0.000 & 0.003 & 0.001 & 0.005 & 0.060 & 0.000 & 0.000 & 0.000 \\
\hline $\mathrm{Ca}$ & 0.000 & 0.000 & 0.000 & 0.002 & 0.000 & 0.040 & 0.000 & 0.000 & 0.000 \\
\hline XMn & 0.084 & 0.306 & 0.103 & 0.185 & 0.156 & 0.133 & 0.209 & 0.246 & 0.006 \\
\hline
\end{tabular}

sporadically appear. The amphibole is euhedral and can be found included in plagioclase. Its composition varies from titanian ferro-edenite to Mg-hornblende. Other amphibole crystals are clearly exsolved and recrystallized as subsolidus actinolite.

There are several generations of quartz and plagioclase in most of the peraluminous granites. The compositional range and crystallization sequence is very similar in the majority of the studied granites. Generally, there is an evolution from Qtz-Pl( $\left.\mathrm{An}_{60-40}\right)$ toward Qtz-Pl( $\left.\mathrm{An}_{10}\right)-\mathrm{Kfs}$ in monzogranite. In the leucocratic types, plagioclase is only weakly zoned and no different generations are present. The leucogranitic rocks show equigranular textures with Qtz, $\mathrm{Pl}\left(\mathrm{An}_{10-5}\right)$ and Kfs.

In the majority of the epizonal plutons volatile exsolution is evidenced in some segregates and pegmatitic bodies, which generated various mineral assemblages but have not been thoroughly studied. Depending on the pegmatite type they include fluorite, topaz, beryl, lepidolite, calcite, and normally tourmaline and muscovite, some- times accompained by garnet, cordierite and ironrich biotite.

\section{4.- ATFM mineral vs. whole-rock compositions}

Minerals display chemical characters reflecting the composition of the magma in which they were formed. The most obvious case is that of biotite. Other ATFM phases show the same chemical variability irrespectively of the peraluminosity of the granite series.

It has been already shown that in biotite, the Al content varies substantially depending on the granite type (Fig. 3), also, its redox state seems to depend on the granite type. There is a decrease in the $\mathrm{Fe}^{3+} /\left(\mathrm{Fe}^{2+}+\mathrm{Fe}^{3+}\right)$ ratio in the mica with increasing in $\mathrm{SiO}_{2}$ of the whole rock in both peraluminous granite types (Fig. 7), but this correlation is more difficult to establish in the more acid types. Thus, $\mathrm{X}_{\mathrm{Fe} 3+}$ seems to be plutondependent.

Other chemical parameters of ATFM minerals 


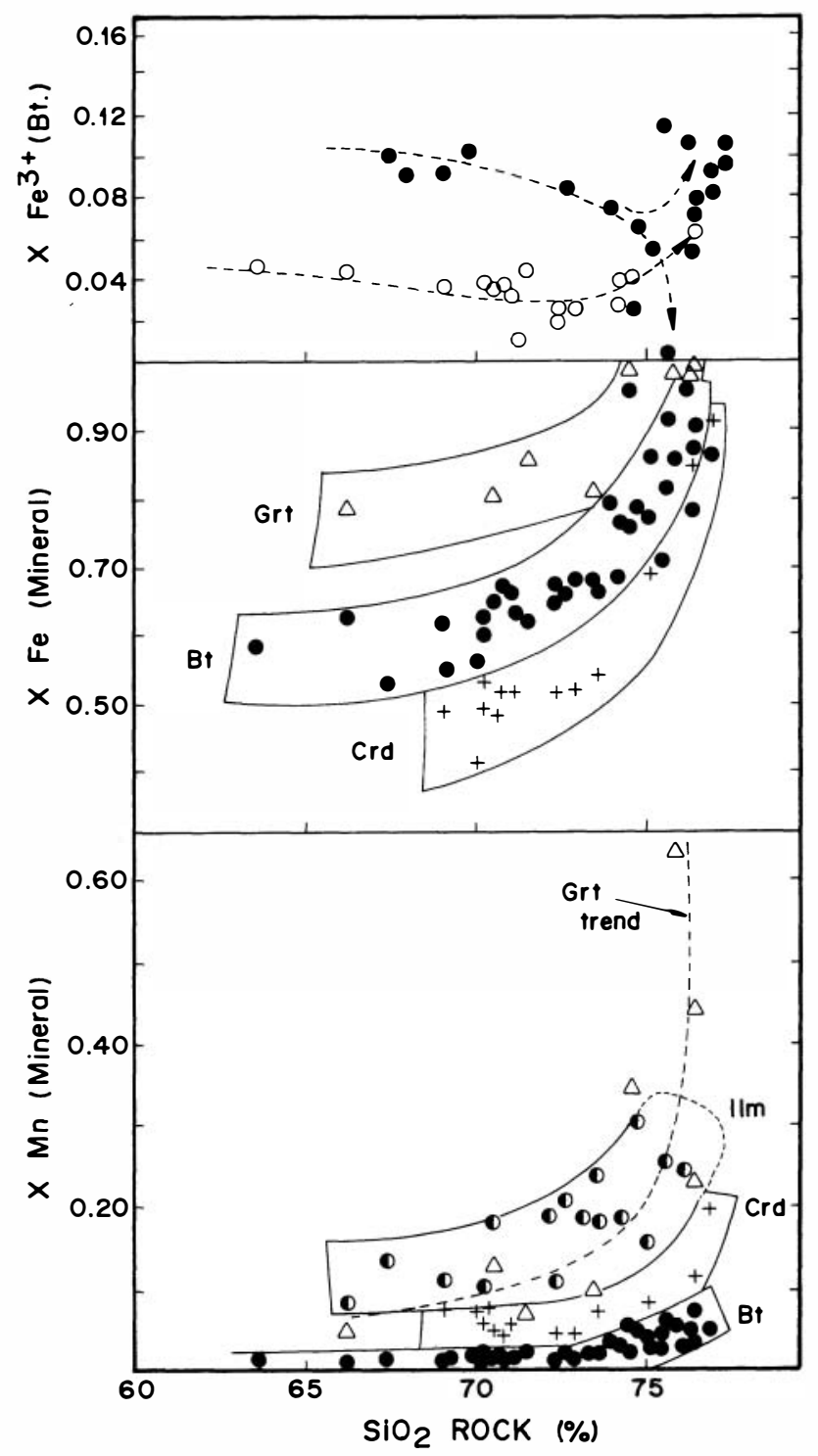

Fig. 7. Plots of $\mathrm{XFe}^{3+}$ (biotites) and $\mathrm{XFe}$ and $\mathrm{XMn}$ of ATFM minerals $v s$. whole-rock $\mathrm{SiO}_{2}$. Except for $\mathrm{XFe}^{3+}$ of biotite, the PS and PI granites have not been distinguished because they plot in the same trends. Mineral symbols are as follow: filled circles $=$ biotites, crosses $=$ cordierites, triangles $=$ garnets, half-filled circles $=$ ilmenites.

seem to be more dependent on the degree of evolution of the magma. In Fig. 7 a positive correlation between $\mathrm{X}_{\mathrm{Fe}}$ in biotite and $\mathrm{SiO}_{2}$ in whole rock can be observed. This correlation is typical of ilmenite-bearing granitic series (Czamanske $e t$ al., 1981). The correlation is perhaps slightly better defined in the PS granites. This trend contrasts with that seen in metaluminous granites in which $\mathrm{X}_{\mathrm{Fe}}$ of biotite decreases or is constant in rocks with variable $\mathrm{SiO}_{2}$ (Czamanske et al., 1981; De Pieri \& Jobstraibizer, 1983).

The positive correlation between $\mathrm{X}_{\mathrm{Fe}}$ in the minerals and $\mathrm{SiO}_{2}$ in the whole rock is also shown by cordierite and garnet (Fig. 7). In 
general, it is observed that $\mathrm{X}_{\mathrm{Fe}}$ garnet $>\mathrm{X}_{\mathrm{Fe}}$ biotite $>\mathrm{X}_{\mathrm{Fe}}$ cordierite for the same $\mathrm{SiO}_{2}$ content in the whole rock, $\mathrm{X}_{\mathrm{Fe}}$ in the whole rock being similar to that in the biotite, which coincides with the experimental data on peraluminous melts in equilibrium with mafic phases (Ellis, 1986; Holtz \& Johannes, 1991).

It is noteworthy that the increase in $\mathrm{X}_{\mathrm{Fe}}$ in minerals is more pronounced in granites with $\mathrm{SiO}_{2}$ $>74 \%$. This change in the general trend had been already observed only for biotite (Czamanske et al., 1981, Fig. 4) but it is also present in cordierite, and to a lesser extent in garnet (Fig. 7). This is the result of the low $\mathrm{Mg}$ content of these rocks, because there is a good correlation between $\mathrm{X}_{\mathrm{Fe}}$ in minerals and the whole rock, as was also noticed by Czamanske et al. (1981) in ilmenite-bearing granite series.

$\mathrm{X}_{\mathrm{Mn}}\left(\mathrm{Mn} /\left(\mathrm{Mn}+\mathrm{Fe}^{2+}\right)\right)$ in ATFM minerals is another chemical parameter which changes with magmatic differentation. This ratio increases regularly with increase in $\mathrm{SiO}_{2}$ of the whole rock (Fig. 7), and is particularly marked in the more acid granites, in which Mn behaves as an incompatible element, as it has been noticed by other authors (Czamanske et al., 1981; Whalen \& Chappell, 1988). This chemical trend for ATFM minerals (Fig. 7) have never been graphically reported for a so complete magmatic series. As observed in Fig. 7 a marked inflection toward higher Mn contents in all ATFM phases appear at $\mathrm{SiO}_{2}>74 \%$.

In Fig. 7 it is also possible to observe that $X_{M n}$ ilmenite $\cong X_{M n}$ garnet $>X_{M n}$ cordierite $>X_{M n}$ biotite indicating a similar $\mathrm{Kd}^{\mathrm{Mn}}$ in ilmenite and garnet. If confirmed by additional data, these $\mathrm{Kd}^{\mathrm{Mn}}$ values would contradict the experimental results and previous observations recorded by Pownceby et al. (1987). Nevertheless, the variation in $\mathrm{X}_{\mathrm{Mn}}$ (Ilm/Grt) in Fig. 7 does not show marked differences as suggested by the data of Pownceby et al. (1987). These similarity of $X_{M n}$ in ilmenite and garnet is also shown by other plutons (Stumpy Point pluton, Speer, 1981) but in highly-fractionated granites and pegmatites, $\mathrm{Mn}$ is preferentially concentrated in garnet (Speer \& Becker, 1992). This fact suggests that the Mn content in garnet is at a maximun when ilmenite is absent.

The increase in Mn content of ATFM phases is certainly marked when $\mathrm{XFe}$ in a mineral is very high, losing the linear correlation between both components, and defining an increase of two or three fold in Mn content.

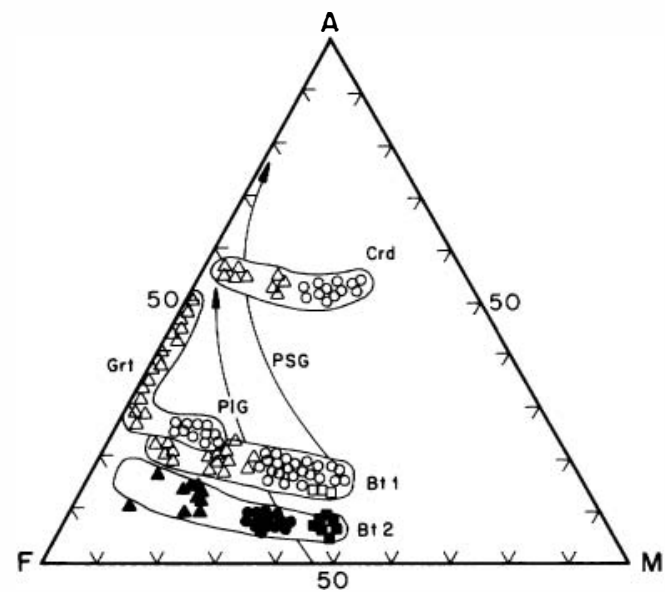

Fig. 8. AFM ternary diagram after Abbott (1981) showing the compositional fields of minerals and whole rocks from Central Spain granites. Bt-1 and Bt- 2 refer to PS and PI biotites repectively. The general trends of peraluminous (PSG) and subaluminous (PIG) granites are indicated. Same symbols as in Fig. 3.

\section{5.- Comments on AFM liquidus model}

In an AFM projection of the mineral phases (Fig. 8), a slight but definite increase in A value with differentiation can be observed. This feature, not apparent in previous studies (Clarke, 1981; Speer, 1981), is consequence of the progressive decrease in the $\mathrm{Fe}-\mathrm{Mg}$ content of the mineral. In garnet, the substitution of Fe by $\mathrm{Mn}$ is the factor which mainly induces the shift of the composition toward higher A values (Abbott, 1981).

All the AFM minerals tend to plot on the AF side on the AFM diagram because the Fe endmembers have a lower crystallization temperature with respect to the $\mathrm{Mg}$ end-members. What is more noticeable is that the projection of the whole rock compositions on the AFM diagram departs from the Abbott \& Clarke (1979) model. Thus, the leucogranites do not have a high F/A ratio, but rather the opposite, which is also more pronunced in the more felsic compositions. The liquidus surfaces proposed by Abbott \& Clarke (1979) should have a greater slope toward the A corner as in the granitic series considered here (Fig. 8), and as common in granite differentiation process (see also Fig. 9A of Nabelek et al., 1992). In the more fractionated PI granites AFM 

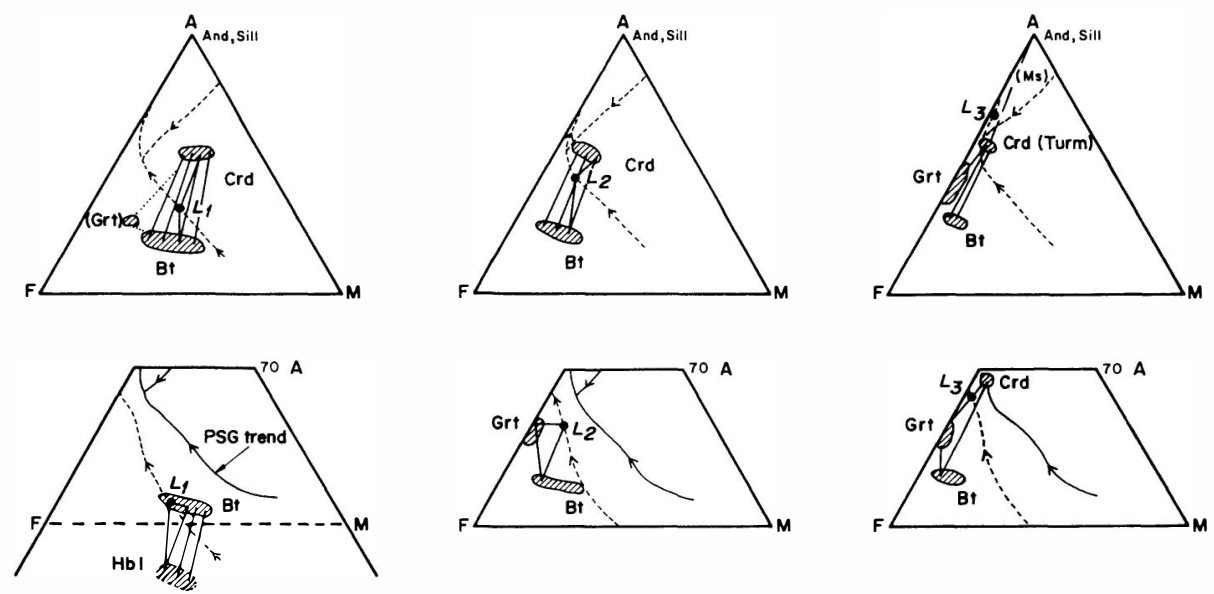

Fig. 9. Possible AFM liquidus evolution for PS granites (upper row) and PI granites (lower row) of Central Spain. Magma compositions labelled L1, L2 and L3 corresponds to monzogranitic, leucogranitic and aplogranitic averaged compositions in each granitic series. In several of the less evolved liquids there is evidence of the mineral reaction $\mathrm{L} 1+\mathrm{Grt}=\mathrm{Crd}+\mathrm{Bt}(\mathrm{PS})$ or $\mathrm{L} 1+$ Amphibole $=\mathrm{Bt}(\mathrm{PI})$. In the same way, in highly fractionated liquids (L3) there are textural evidences of the reactions: $\mathrm{L} 3+\mathrm{Bt}=\mathrm{Crd} \pm \mathrm{Grt}$ (nodules in PS and PI granites) and $\mathrm{L} 3+\mathrm{Bt} \pm$ volatile $=\mathrm{Ms} \pm$ Tourmaline (PS granites). Further explanations in the text.

phases more peraluminous than biotite can occur such as is the case of the La Cabrera pluton that bears garnet and scarce cordierite.

In the diagrams of Fig. 9, the compositional relation between several AFM minerals and granitoid composition can be observed. In some cases, the whole rock composition does not plot on the tie-lines of the AFM phases or in the fields defined by these lines indicating an excess in one of the AFM components, usually in the A value (peraluminosity), that cannot be indicated in the projected mineral phases. This is more evident in the more acid granites because of the abundance of muscovite (of pegmatitic and/or deuteric origin), tourmaline, and other late phases. In general, there is a good correlation between the composition of the monzogranitic (L1) and leucogranitic (L2) magmas, and the highly fractionated or aplo-pegmatitic (L3) liquids and their associated AFM mineral assemblage (Fig. 9). Nevertheless, it must be remembered that the use of true compositions of the rocks disturbs the AFM system, in which the effect of Mn increase in almost all these mineral phases is not considered and this change its projection fields (Abbott, 1981). In magmas closest to volatile saturation, and with lower liquidus temperatures (aplo-pegmatitic) the stability fields of muscovite and/or tourmaline overrun or eliminate the fields of cordierite, aluminum silicate and garnet as shown by Abbott \& Clarke (1979).

In general, the petrographic observation of the granitic types tend to a certain kind of mineral sequence from those crystallizing at near liquidus conditions to those of later growth and typically of the most aluminous phases. These differences in crystallization times make the mutual equilibrium relations between minerals difficult to establish. The common mineral disequilibrium features in different phases of the same rock sample (i.e. igneous zoning in garnets, primary stage ilmenite and biotite preserved as inclusions, etc) indicate that there are additional factors, such as the evolution to residual composition of the liquids, or the simultaneous growth of phases with different $\mathrm{Kd}$ values, that can play a major role in the composition of the ATFM minerals in the granitoids.

Taking into consideration the aforementioned factors, we estimate the P-T region of crystallization of the studied granite types using the AFM liquidus model of Abbott \& Clarke (1979, Fig. 4). The simultaneous cordierite-biotite crystallization in peraluminous granites is consistent with conditions below the " $n-g-4$ " field of the AFM topology. The intermediate to Fe-rich com- 
positions of the AFM phases considered here suggest conditions in the low-pressure part of this diagram, i.e. pressures below 4 kbar. On the other hand, the absence of garnet + aluminum silicate associations in almost all the plutons indicates conditions normally below the " $\mathrm{e}$ " point of Abbott and Clarke, i.e. pressures lower than 2.5 kbar. These estimates agree with those made based on thermobarometrical calculations in the metamorphic paragenesis of the contact-aureole materials (Bellido, 1979) and are also consistent with the absence of primary muscovite in almost all these granites.

Acknowledgements: We are grateful to N. Snelling and E. Stephens for their critical review and for the revision of the English version of the text. This paper has benefited greatly from reviews of B. Bonin, and A. M. Neiva. We also appreciate very much the detailed revision of A. Rottura and two anonymous reviewers which greatly improve the quality of the manuscript. We thank R. Casillas and M. J. Huertas for their collaboration in microprobe analyses at the University of Clermont Ferrand (France). This work is finantially supported by a CICYT (PB 88/0117) project of the Spanish Ministerio de Educación y Ciencia.

\section{6.- References}

Abbott, R.N. (1981): AFM liquidus projections for granitic magmas, with special reference to hornblende, biotite and garnet. Can. Mineral., 19, 103110.

Abbott, R.N. \& Clarke, D.B. (1979): Hypothetical liquidus relationships in the subsystem $\mathrm{Al}_{2} \mathrm{O}_{3}-\mathrm{FeO}$ $\mathrm{MgO}$ projected from quartz, alkali feldspar and plagioclase for $\mathrm{a}\left(\mathrm{H}_{2} \mathrm{O}\right)<1$. Can. Mineral., 17, 549-560.

Afifi, M.A. \& Essene, E.J. (1988): MINFILE: a microcomputer program for storage and manipulation of chemical data on minerals. Am. Mineral., 73, 446448.

Alburquerque, C.A.R. (1973): Geochemistry of biotites from granitic rocks, Northern Portugal. Geochim. Cosmochim. Acta, 37, 1779-1802.

Andonaegui, P. (1990): Geoquímica y geocronología de los granitoides del sur de Toledo. Tesis Doctoral (23/92), Universidad Complutense de Madrid, $365 \mathrm{p}$.

Aparicio, A., Barrera, J.L., Caraballo, J.M., Peinado, M. \& Tinao, J.M. (1975): Los materiales graníticos del Sistema Central Español. Memor. I.G.M.E., 88, 1-145.
Barbarin, B. (1990): Granitoids: main petrogenetic classifications in relation to origin and tectonic setting. Geol. J., 25, 227-238.

Barbero, L. \& Villaseca, C. (1992): The Layos Granite, Hercynian Complex of Toledo (Spain): an example of parautochthonous restite- rich granite in a granulitic area. Trans. R. Soc. Edinburgh: Earth Sci., 83, 127-138.

Bellido, F. (1979): Estudio petrológico y geoquímico del plutón granítico de La Cabrera. Tesis Doctoral, Universidad Complutense de Madrid, $331 \mathrm{p}$.

Brandebourger, E. (1984): Les granitoides hercyniens tardifs de la Sierra de Guadarrama (Système Central Espagnol). Thèse Doctorat, Univ. Lorraine, $209 \mathrm{p}$.

Bruiyn, H. de, Westuizen, W.A. van der \& Schoch, A.E. (1983): The estimation of $\mathrm{FeO}, \mathrm{F}$ and $\mathrm{H}_{2} \mathrm{O}^{+}$ by regression in microprobe analyses of natural biotites. J. Trace and microprobe Techn., 1, 399-413.

Casillas, R. (1989): Las asociaciones plutónicas tardihercínicas del sector occidental de la Sierra de Guadarrama - Sistema Central Español, (Las Navas del Marqués-San Martín de Valdeiglesias). Petrología, génesis y evolución. Tesis Doctoral (307/89), Universidad Complutense de Madrid, 316 p.

Chappell, B.W. \& White, A.J.R. (1974): Two contrasting granite types. Pacific Geol., 8, 173-174.

Chappell, B.W., White, A.J.R. \& Williams, I.S. (1991): A transverse section through granites of the Lachlan Fold Belt. Excursion guide "Second Hutton Symposium", BMR/Geol. and Geophy., Record 1991/22, $125 \mathrm{p}$.

Chappell, B.W., White, A.J.R. \& Wyborn, D. (1987): The importance of residual source material (restite) in granite petrogenesis. J. Petrol., 28, 1111-1138.

Clarke, D.B. (1981): The mineralogy of peraluminous granites: a review. Can. Mineral., 19, 3-17.

Clemens, J. D. \& Wall, V. J. (1988): Controls on the mineralogy of S-type volcanic and plutonic rocks. Lithos, 21, 53-66.

Czamanske, G.K., Ishihara, S. \& Atkin, S.A. (1981): Chemistry of rock-forming minerals of the Cretaceous-Paleocene batholith in southwestern Japan and implications for magma genesis. $J$. Geoph. Research, 86 B11, 10431-10469.

Debon, F. \& Le Fort, P. (1983): A chemical-mineralogical classification of common plutonic rocks and associations. Trans. R. Soc. Edinburgh: Earth Sci., 73, 135-149.

De Pieri, R. \& Jobstraibizer, P.G. (1983): Crystal chemistry of biotites from dioritic to granodioritic rock-types of Adamello Massif (Northern Italy). N. Jb. Mineral. Abh., 148, 58-82.

Du Bray, E.A. (1988): Garnet compositions and their use as indicators of peraluminous granítoid petrogenesis - southeastern Arabian Shield. Contrib. Mineral. Petrol., 100, 205-212. 
Dymek, F.R. (1983): Titanium, aluminium and interlayer cation substitution in biotite from high-grade gneisses, West Greenland. Am. Mineral., 68, 880899.

Ellis, D.J. (1986): Garnet-liquid $\mathrm{Fe}^{2+}-\mathrm{Mg}$ equilibria and implications for the beginning of melting in the crust and subduction zones. Amer. Jour. Sci., 286, 765-791.

Gordillo, C.E., Schreyer, W., Werding, G. \& Abraham, K. (1985): Lithium in Na Be-cordierites from El Peñón, Sierra de Córdoba, Argentina. Contrib. Mineral. Petrol., 90, 93-101.

Green, T.H. (1992): Experimental phase equilibrium studies of garnet-bearing I-type volcanics and highlevel intrusives from Northland, New Zealand. Trans. R. Soc. Edinburgh: Earth Sci., 83, 429-438.

Holub, F.V., Machart, J. \& Mraz, L. (1981): Tourmaline-bearing nodules from the Eisgarn granite in the Volary area (Southern Bohemia). Acta Univ. Carolinae Geol., 4, 363-377.

Holtz, F. \& Johannes, W. (1991): Genesis of peraluminous granites I. Experimental investigations of melt compositions at 3 and $5 \mathrm{~kb}$ and various $\mathrm{H}_{2} \mathrm{O}$ activities. J. Petrol., 32, 935- 958.

Ibarrola, E., Villaseca, C., Vialette, Y., Fúster, J.M., Navidad, M., Peinado, M. \& Casquet, C. (1987): Dating of hercynian granites in the Sierra de Guadarrama (Spanish Central System). in "Geología de los granitoides y rocas asociadas del Macizo Hespérico", Bea, F., Carnicero, A., Gonzalo, J.C., López-Plaza, M. \& Rodríguez-Alonso, M.D., ed., Rueda, Madrid, 377-383.

Kerrick, D.M. \& Speer, J.A. (1988): The role of minor element solid solution on the andalusite-sillimanite equilibrium in metapelites and peraluminous granitoids. Amer. Jour. Sci., 288, 152-192.

Lalonde, A.E. \& Bernard, P. (1993): Composition and color of biotite from granites: two useful properties in the characterization of plutonic suites from the Hepburn internal zone of Wopmay orogen, Northwest territories. Can. Mineral., 31, 203-217.

Ligget, D.L. (1990): Geochemistry of the garnet-bearing Tharps Peak granodiorite and its relation to other members of the Lake Kaweah intrusive suite, southwestern Sierra Nevada, California. in " The Nature and Origin of Cordilleran magmatism", Anderson, J.L., ed. Geol. Soc. America Memoir, 174, 225-236.

Miyashiro, A. (1957): Cordierite-indialite relations. Amer. Jour. Sci., 255, 43-62.

Nabelek, P.I., Russ-Nabelek, C. \& Denison, J.R. (1992): The generation and crystallization conditions of the Proterozoic Harney Peak Leucogranite, Black Hills, South Dakota, USA: petrological and geochemical constraints. Contrib. Mineral. Petrol., 110, 173-191.

Nachit, H., Razafimahefa, N, Stussi, J. M. \& Carron,
J. P. (1985): Composition chimique des biotites et typologie magmatique des granitoïdes. C. R. Acad. Sci. Paris, 301-11, 813-818.

Neiva, A.M.R., Neiva, J.M. \& Parry, S.J. (1987): Geochemistry of the granitic rocks and their minerals from Serra da Estrela, Central Portugal. Geochim. Cosmochim. Acta, 51, 439-454.

Nockolds, S.R. (1947): The relation between chemical composition and paragenesis in the biotite micas of igneous rocks. Amer. Jour. Sci., 245, 401-420.

Pérez-Soba, C. (1991): Petrología y Geoquímica del macizo granítico de La Pedriza, Sistema Central Español. Tesis Doctoral (282/92), Universidad Complutense de Madrid, $225 \mathrm{p}$.

Pichavant, M., Kontak, D.J., Valencia-Herrera, J. \& Clark, A.H. (1988): The Miocene-Pliocene Macusani volcanics, SE Peru. I. Mineralogy and magmatic evolution of a two-mica aluminosilicatebearing ignimbrite suite. Contrib. Mineral. Petrol., 100, 300-324.

Pierrel, L. (1987): Les grenats: indicateurs magmatiques de l'évolution ultime des leucogranites, en particulier porteurs d'étain, dans la différenciation géochimique du linéament granitique hercynien de Beariz-la mine Sultana, Galice, Espagne. Bull. Soc. Géol. France, III-2, 353-360.

Pitcher, W.S. (1983): Granite Type and Tectonic Environment. in "Mountain Building Processes", Hsu, K., ed., Academic Press, London, 19-40.

Pownceby, M.I., Wall, V.J. \& O'Neill, H.St.C. (1987): Fe-Mn partitioning between garnet and ilmenite: experimental calibration and applications. Contrib. Mineral. Petrol., 97, 116-126.

Puziewicz, J. \& Johannes, W. (1988): Phase equilibria and compositions of $\mathrm{Fe}-\mathrm{Mg}$ - $\mathrm{Al}$ minerals and melts in water-saturated peraluminous granitic systems. Contrib. Mineral. Petrol., 97, 116-126.

Robinson, P. (1991): The eye of the petrographer, the mind of the petrologist. Am. Mineral., 76, 1781-1810.

Schreyer, W., Gordillo, C.E. \& Werding, G. (1979): A new sodian-beryllian cordierite from Soto, Argentina, and the relationship between distortion index, Be-content and state of hydration. Contrib. Mineral. Petrol., 70, 421-428.

Secchi, F.A., Brotzu, P. \& Callegari, E. (1991): The Arburese igneous complex (SW Sardinia, Italy), an example of dominant igneous fractionation leading to peraluminous cordierite-bearing leucogranites as residual melts. Chemical Geol., 92, 213-249.

Shimura, T., Komatsu, M. \& Iiyama, J.T. (1992): Genesis of the lower crustal garnet-orthopyroxene tonalites (S-type) of the Hidaka Metamorphic Belt, northern Japan. Trans. R. Soc. Edinburgh: Earth Sci., 83, 259-268.

Spear, F.S. (1991): On the interpretation of peak metamorphic temperatures in ligth of garnet diffussion during cooling. J. Met. Geol., 9, 379-388. 
Speer, J.A. (1981): Petrology of cordierite- and almandine + cordierite-bearing biotite granitoid plutons of the southern Appalachian Piedmont, USA. Can. Mineral., 19, 35-46.

Speer, J.A. \& Becker, S.W. (1992): Evolution of magmatic and subsolidus AFM mineral assemblages in granitoid rocks: Biotite, muscovite, and garnet in the Cuffytown Creek pluton, South Carolina. Am. Mineral., 77, 821-833.

Vialette, Y. Bellido, F., Fúster, J.M. \& Ibarrola, E. (1981): Données géochronologiques sur les granites de La Cabrera. Cuad. Geol. Ibérica, 7, 327-335.

Villaseca, C., Barbero, L., Huertas, M. J., Andonaegui, P. \& Bellido, F. (1993): A cross- section through Hercynian granites of Central Iberian Zone. Excursion Guide. Servicio de Publicaciones del C.S.I.C., Madrid, 122 p.

Vry, J.K., Brown, P.E. \& Valley, J.W. (1990): Cordierite volatile content and the role of $\mathrm{CO}_{2}$ in highgrade metamorphism. Am. Mineral., 75, 71-88.
Whalen, J.B. \& Chappell, B.W. (1988): Opaque mineralogy and mafic mineral chemistry of I- and S-type granites of the Lachlan Fold belt, southeast Australia. Am. Mineral., 73, 281-296.

White, A.J.R. \& Chappell, B.W. (1988): Some supracrustal (S-type) granites of the Lachlan Fold Belt. Trans. R. Soc. Edinburgh: Earth Sci., 79, 169-181.

Wones, R. D. \& Eugster, M. P. (1965): Stability of biotite: experimental theory and application. Am. Mineral., 50, 1228-1272.

Zen, E. (1988): Phase relations of peraluminous granitic rocks and their petrogenetic implications. Ann. Rev. Earth Planet. Sci., 16, 21-51. 